\title{
Director's Choice: Report on Selected Acquisitions, 1985-89
}

\section{Phyllis Lambert}

Volume 16, numéro 2, 1989

Études sur l'architecture et son environnement

Studies on Architecture and its Environment

URI : https://id.erudit.org/iderudit/1073143ar

DOI : https://doi.org/10.7202/1073143ar

Aller au sommaire du numéro

\section{Éditeur(s)}

UAAC-AAUC (University Art Association of Canada | Association d'art des universités du Canada)

\section{ISSN}

0315-9906 (imprimé)

1918-4778 (numérique)

Découvrir la revue

\section{Citer cet article}

Lambert, P. (1989). Director's Choice: Report on Selected Acquisitions, 1985-89. RACAR : Revue d'art canadienne / Canadian Art Review, 16(2), 121-130. https://doi.org/10.7202/1073143ar

\section{Résumé de l'article}

La manière dont se sont constituées les collections du CCA a été exposée dans la publication Les débuts/The First Five Years, 1979-1984 (Montréal, 1988). Le document intitulé « Director's Choice: Report on Selected Acquisitions, 1985-89 ", énumère et décrit les volumes ajoutés à la bibliothèque après 1984, ainsi que les dessins, les estampes, les photographies et les collections d'archives. L'un et l'autre expliquent comment les acquisitions récentes stimulent la recherche concernant les fonds déjà acquis et comment elles ouvrent de nouveaux champs d'investigation. Dans le présent rapport, les oeuvres sont classées de la façon suivante : dessins et livres de la Renaissance, fortifications, collections spéciales, périodiques, bâtiments particuliers, archives-urbanisme et édifices résidentiels, fonds d'architectes—et photographies. Le rapport sur les acquisitions se termine par la liste des publications du CCA et par une autre liste des ouvrages ayant trait aux collections du CCA. Les images reproduites ici donnent un aperçu aussi large que possible des collections du CCA, étant donné qu'ils s'ajoutent aux illustrations des autres articles de ce numéro de RACAR et aux publications du CCA. Certaines de ces images ont été réalisées pour les fins les plus grandioses et d'autres pour des motifs très humbles. Elles ont été faites pour résoudre des problèmes propres au domaine bâti. Elles démontrent que les différents moyens d'expression vont du livre sans prétention sur un bâtiment simple jusqu'aux exemples les plus remarquables, tant du point de vue du sujet que de la facture. Il est à noter que l'authenticité, la qualité et le bon état des objets de collection sont les caractéristiques essentielles des oeuvres réunies par le CCA. La mauvaise qualité d'une oeuvre nuit à sa compréhension. Celles des collections du CCA sont conservées et exposées dans des conditions optimales; ainsi, les visiteurs et les chercheurs peuvent examiner simultanément et en profondeur les dessins, les livres et les photographies du quinzième siècle à nos jours-des documents du monde construit par l'homme.
Tous droits réservés (C UAAC-AAUC (University Art Association of Canada | Association d'art des universités du Canada), 1989
Ce document est protégé par la loi sur le droit d'auteur. L’utilisation des services d'Érudit (y compris la reproduction) est assujettie à sa politique d'utilisation que vous pouvez consulter en ligne.

https://apropos.erudit.org/fr/usagers/politique-dutilisation/ 


\title{
Director's Choice: Report on Selected Acquisitions, 1985-89
}

\author{
PHYLLIS LAMBERT
}

Director and President

\section{RÉSUMÉ:}

La manière dont se sont constituées les collections du Cc:A a été exposée dans la publication Les débuts/The First Five Years, 1979-1984 (Montréal, 1988). Le document intitulé "Director's Choice: Report on Selected Acquisitions, 1985-89 ", énumère et décrit lcs volumes ajoutés à la bibliothèque après 1984, ainsi que les dessins, les estampes, les photographies et les collections d'archives. L'un et l'autre expliquent comment les acquisitions récentes stimulent la recherche concernant les fonds déjà acquis ct comment elles ouvrent de nouveaux champs d'investigation. Dans le présent rapport, les oeuvres sont classées de la façon suivante : dessins et livres de la Renaissance, fortifications, collections spéciales, périodiques, bâtiments particuliers, archivesurbanisme et édifices résidentiels, fonds d'architcctes - et photographies. Le rapport sur les acquisitions se termine par la liste des publications du CCA et par une autre liste des ouvrages ayant trait aux collections du cCA. Les images reproduites ici donnent un aperçu aussi large que possible des collections du cc.A, étant donné (qu'ils s'ajoutent aux illustrations des autres articles de ce numéro de RAcar et aux publications du CC.A. Certaines de ces images ont été réalisées pour les fins les plus grandioses et d'autres pour des motifs très humbles. Elles ont été faites pour résoudre des problèmes propres au domaine bâti. Elles démontrent que les différents moyens d'expression vont du livre sans prétention sur un bâtiment simple jusqu'aux exemples les plus remarquables, tant du point de vue du sujet que de la facture. Il est à noter que l'authenticité, la qualité et le bon état des objets de collection sont les caractéristiques essentielles des ocuvres réunies par le cc.A. la mauvaise qualité d'une oeuvre nuit à sa compréhension. Celles des collections du cca sont conservées et exposées dans des conditions optimales; ainsi, les visiteurs et les chercheurs peuvent examiner simultanément et en profondeur les dessins, les livres et les photographies du quinzième siècle à nos jours - des documents du monde construit par l'homme.
Drawings are projections through which architects visualize, test and order relationships. Along with prints, photographs, computer images and texts they convey intentionality to client and contractor and, in published form, to a broad public. The built world is conceived and presented through such images which preserve knowledge of the past and project how we will live in the future.

(Phyllis Lambert, Foreword, Architecture and Its Image)

A study centre and a museum, the Centre Canadien d'Architecture/Canadian Centre for Architecture is founded on its collections. The collections of the CCA are integral to its dual purpose: a study centre for advanced research in the history and understanding of architecture and the built environment, and a museum dedicated to encouraging informed participation in decisions about the future of cities and their buildings. It follows that the collection is fundamental to advanced research; the objects which compose it give direct evidence of the hand that made them.

Viewed as a whole, the collection is concerned with the art of architecture. It is composed principally of prints, drawings, monographs, serials, photographs, and archives which are interrelated. The ccA's collection is not limited by time and place; it is not concerned with a specific period of time, nor with the architecture of a single country. The depth and breadth of the different collections are to some extent related to the nature of the medium or genre of each collection; the Library will always be the most comprehensive, collecting the printed literature of architecture. In building and continually strengthening a scholarly corpus of books and auxiliary materials as a basis for advanced research in the field, the Library forms a 
historical collection with areas of particular subject strengths which are important in themselves (e.g., the Trissino collection of guides to Italian cities) and which also support research on other collections at the CCA. For example, there are books on sixteenth-century sketch books and on theatre studies related to works held by the Prints and Drawings Collection and on bridges, and Indian and Japanese temples which are depicted in the Photographs Collection.

Drawings are collected in order to understand how an architect thinks conceptually and how a building evolves from the initial ideas developed in preliminary sketches through working and contract drawings. Albums and sketch books and coherent groups of drawings made or collected by individual architects or firms of architects provide such study matter. Likewise, individual isolated shects, when taken together, contribute information towards understanding and clarifying attitudes pertaining to a particular place, period or building type, to ideas and concepts, to cultural history, to the interaction of architect, client and builders. New acquisitions must add to areas of strength and to the historical coverage of the collection, and significant concepts, modes, codes, and conventions of representation in architecture must be comprehensively included.

Vedute as representations of buildings and the built environment are collected in print form because of their potential as replicative material in order to disseminate visual information on buildings; as such they influence architect and client both near and far. Similarly, photographs have the same potential and are collected as evidence of both building and architectural history and of the history of the art of photography. The CCA encourages the study of photography as a medium because it is closcly bound to the history of architecture which in turn is closely tied to the history of photography. 'The cca's collection also contains printed and photographic records (in single prints or in suites) of buildings, gardens, and estates which were made sometimes as travel documents and other times as architectural proposals. We include in our holdings, engravings and lithographs made to reproduce working drawings before photo-mechanical processes took over in the twentieth century.

The cca Archives was established to gather the most complete documentation possible on the work of an architect. Ideally, an architectural archive is composed of all the holdings of an office for projects built or not built, sketches and working drawings, specifications, blueprints, shop drawings, as-built drawings, models, correspondence, accounts and time sheets, photographs.
These records, along with office libraries, personal memorabilia, draughting tools, travel sketches, works of art in various media made or collected by the architect, and other objects shed light on the architect's life and interests. They provide the most complete instrument for a researcher, supplying insight into the activity of a single architect as an individual practitioner and as a representative model of his period. The Cormier archive, which the CCA acquired in its first five years, represents such a record, a rare example of an intact office archive.

The formation of the collections is discussed in Les débuts/The First Five Years, 1979-1984. Now that the CCA building is open and the collections are accessible to scholars, it is appropriate, in this issue of RACAR, to discuss major aspects of collection development which have occurred at the CCA from 1985 to 1989. In general, this report does not include acquisitions illustrated in other CCA publications which are listed at the end of this article. The "Director's Choice" is directed towards coherent groups or single objects-books, drawings, prints and photographs - that have entered the collection and which either strengthen research in existing holdings or open new areas of research. For this report, I have selected objects grouped as follows: Renaissance Drawings and Imprints, Fortifications, Special Collections, Periodicals, Individual Buildings, Archives-Urban Design and Housing and Architects' Fonds-and Photographs.

\section{RENAISSANCE DRAWINGS AND IMPRINTS}

At the beginning of the second five years, the CCA focused on the acquisition of fifteenth- and sixteenth-century documents considered valuable for research. Amongst the noteworthy acquisitions of Renaissance drawings is a group of seven folios from a sketch book attributed to Simone del Pollaiuolo, known as Il Cronaca. These drawings, executed between 1484 and 1500 (Fig. 105), show the importance for the Renaissance of the study of ancient monuments. ${ }^{1}$ In addition, they reveal Il Cronaca's interest in comparing details from Roman ruins with those buildings of medieval Florence that were believed at the time to have been constructed in Roman Antiquity. An extraordinary manuscript on vellum as well as two suites of engravings by members of the workshop of Jacques Androuet Du Cerceau, the Grand temples et habitations fortifiés and Détails d'ordres d'architecture are discussed by Myra Nan Rosenfeld (see p. $132 \mathrm{ff}$.).

I See "A Syntax for Antiquity," in Architecture and Its Image, edited by Eve Blau and Edward Kaufman (Montréal, 1989), 200-203. 
While there is not an extensive body of books on architecture printed before 1500 , the growing holdings of the CCA were augmented by the addition of two incunabula which provide evidence of the nature of the earliest imprints in the field: Geometria deutsch (Nuremburg, ca. 1497) by Matthäus Roritzer and Hypnerotomachia Poliphili (Venice, 1499) by Francesco Colonna. Matthäus Roritzer (ca. 1435-95) was a master mason from a family of masons involved in large-scale projects in southeastern Germany. The family achieved fame through Matthäus' instructive booklets. His eight-page Geometria deutsch (Fig. 106) remained for some time a fundamental manual on geometry and provides us with rare evidence of how masons drew and prepared their work. It was the major book on geometry used in Germany before the 1525 publication of Dürer's Unterweysung der Messung; Dürer himself learned from Matthäus' manual.

The cca's Hypnerotomachia Poliphili is one of very few known copies of the first edition in a contemporary binding. The significance of the text and the very beautiful woodcuts lies in their expression of classical ideals. The designer of the woodcuts invented rather than represented buildings, gardens, monuments, and ruins, and thereby influenced future architects. For example, the elephant carrying an obelisk (Fig. 107) inspired Bernini's fountain outside S. Maria Sopra Minerva, Rome. 'The cca also has three later editions: Venice, 1545, and Paris, 1546 and 1610 .

With the acquisition of another incunabulum, De architectura libri decem (Venice, 1497) and of Vitruvius teutsch (Nuremberg, 1548), the cca now holds all the major editions and translations of Vitruvius. Many of the sixteenth-century additions to the collection centre around the Bolognese architect Sebastiano Serlio (1475-1555). Rare editions of his treatises joined others in the Library. The first German edition of Serlio's Book Iv, On the Orders, Die Gemaynen Reglen von der Architectur uber die funf Manieren der Gebev, printed in Antwerp by Pieter Coecke in 1542, reveals Serlio's debt to Albrecht Dürer. Coecke's editions of Serlio's books in Dutch, German, and French were important in making his manuals available to practising architects and patrons in northern Europe as well as Italy. A compilation of the first Dutch editions of Serlio's Books I-v, printed in Antwerp between 1539 and 1553, became part of the CCA's collection. Book Iv, On the Orders, published in Dutch, is extremely rare, as is the first French translation of Book Iv, published by Coecke in Antwerp in 1545 which was also acquired by the Library. ${ }^{2}$

2 "A Syntax for Antiquity," 202-203.
The first edition of Serlio's Book vir, De architectura (Frankfurt, 1575), which had been published posthumously in Latin and Italian by Jacopo Strada, also entered the Library. Composed while Serlio lived in France, it is a model book with designs for domestic buildings. Another publication - La Magnificence de la superbe et triomphante entree ... (Lyon, 1549) - points to Serlio's activity in France, as the possible designer with Bernard Salomon of decorations for the entry of Henry II into Lyon. A fête book published in the same year, celebrating the entry of Henry in into Paris, C'est l'ordre qui a esté tenv à la novvelle et ioyeuse entrée... (Paris, 1549), was also acquired by the library (Fig. 108). ${ }^{3}$ Jean Goujon, designer-sculptor, Philibert De l'Orme, architect, and Jean Cousin, painter, designed specific constructions for the Paris entry. Jean Martin, writer-linguist, planned the iconography. At the same time, the Prints and Drawings Collection acquired Twenty-three Illustrations of Entablatures, Capitals, and Bases of the Roman Orders exccuted after engravings by Master $G$. A. with the Caltrop, a contemporary of Serlio who is known to have been active in Rome and Naples between 1538 and 1570. In fact, Master $G$. A. with the Caltrop may have based one of the engravings in the original series on a drawing by Serlio of a Corinthian base.

After he was appointed premier architecte et peintre to Francis I, Serlio had a great influence on two French authors of architectural manuals, Jacques Androuet Du Cerceau (1520-86) and Philibert De l'Orme (1510-70). The volumes by $\mathrm{Du}$ Cerceau in the CCA's collections have been noted above. De l'Orme's Novvelles inventions pour bien bastir, first published in Paris in 1561, was another important addition to the Library's collection. It was one of the first manuals printed in France with detailed information on the methods of timber roofing. It was also the earliest of De l'Orme's publications on architecture and joins Le premier tome de l'architecture of 1567, already in the CCA's collection.

The Latin edition of Sebastian Münster's Cosmographia universalis (Basel, 1554) and Braun and Hogenberg's Civitates orbis terrarum (Cologne, 1572) are other major sixteenth-century publications acquired after 1984. They are important additions to the collection of early cartographic prints and topographical books at the CC:A. Münster's popular book (Fig. 109), published from 1544 to 1628 in different editions in Latin, German, French, Bohemian, Italian, and Polish, provided general knowledge of the world to three generations of lay readers. The 1550 edition is

3 Blau and Kaufman, Architecture and Its Image, 287. 
considered the definitive one because of its more complete text, and the many maps, city views, and illustrative woodcuts. Starting with the 1550 edition, Münster incorporated maps drawn by artists according to current information supplied by local sources. These artists strived to present as real and as accurate views as possible. Braun and Hogenberg continued the practice of depicting towns and cities by inviting information from local sources. Here greater refinement was achieved by the use of etchings instead of woodcuts for their atlas. Photography would be the next step of equal significance in achieving accuracy of representation.

\section{FORTIFI(:ATIONS}

In the last five years, the Canadian Centre for Architecture has strengthened considerably its holdings on fortifications. In 1985, almost 60 titles on the subject were acquired from an English collector. This collection includes three sixteenthcentury treatises: Gabrielle Busca's Della esprgnatione et difesa delle fortezze (Turin, 1598), Girolamo Cataneo's Dell'arte militare libri cinque (Brescia, 1584), and Albrecht Dürer's Etliche underticht zu Befestigung der Stett, Schlosz, und Flecken (Nuremberg, 1527). They joined Dürer's De vrbibus, arcibus castellisque condendis... (Paris, 1535), already in the cca library. Several seventeenth-century works published in Germany, France, Holland, and England by J. H. Behr, M. Dogen, A. Freitach, A. C. Le Maître, Du Praissac, A. M. Mallet, and J. Ozanam are also found in this collection, along with ('rabriel Naudé's Syntagma de studio militari (Rome, 1637), called the first bibliography of printed books and manuscripts on military literature available in French and Italian libraries. The eighteenth-century titles, almost all published in Paris, Vienna or the Hague, include the first and last augmented editions of Belidor's Dictionnaire portatif de l'ingenieur (Paris, 1755 and 1768). The nineteenth-century treatises and manuals include reviews of theories of fortification and of the state of the art of the time. Simon François Gay de Vernon's 1805 Traité élémentaire d'art militaire et de fortification presents us with a compilation of courses on fortification drawn up for the newly established polytechnic schools. An important addition to the CCA's collection of books on fortifications which was acquired separately by the Library is the rare early edition of etchings of triangular bastions and earthworks, Prospettiva di fortificationi designed by Girolamo Portigiani and published, probably in Bologna, towards 1591. It was also conceived as a study in perspective.

A seventeenth-century unpublished manuscript from Germany on fortifications, it is hoped, will help to foster research into seventeenthcentury fortifications. The text of Kurtzer und grundlicher Bericht... was composed before 1636 by Johann Melchior, Ritter von Schwalbach (1581-1653), military commander for the Landgrave of Hesse and for the Duke of Saxony. The illustrations are by Wilhelm Dilich (ca. 157 1-1650), mathematician, architect, cartographer, and designer of court festivals as well as designer of prints and books with topographical information. Dilich produced manuscripts and at the same time published books on fortifications. The cca's manuscript adds to our knowledge of the continued and concurrent use of both forms of information as discussed by Myra Nan Rosenfeld in her article on Jacques Androuet Du Cerceau (see pp. 13145). The manuscript enriches our understanding of the activity of Wilhelm Dilich and of fortification practice, city planning, and German architectural drawing of the period. Dilich's illustrations in the CCA manuscript show the bastions, moats, and bridges, often from a bird's-eye point of view and at obtuse angles, as well as rarely given details of their construction (Fig. 110).

\section{SPECIAI, COILECTIONS}

Four special library collections on the history of Italian cities, on English country houses, on Japanese architecture, and on trade catalogues strengthen the CCA's scholarly resources. The Trissino collection has 2,020 titles on Italian regional and municipal history - it now would be impossible to assemble all these books separately. The books on the cities of Italy are primary research tools on Italian architecture and antiquities (Fig. 111). This collection also includes some books on the theory of art, important for the study of architectural theory; most are extremely rare and unavailable in Canada. The unique strength of the collection lies in its coverage of smaller Italian cities and of such centres as Brescia, Ferrara, Turin and Verona. The oldest work is a very rare copy of the 1494 guide to Bologna, Bononia illustrata by Niccolo Burzio.

The John Harris collection is one of the richest sources in either public or private hands for the study of English country houses and gardens, essential to the history of English art and architecture. The collection of some 340 books and guides, formed over 30 years, reflects the British passion during the eighteenth and nineteenth centuries for visiting stately houses and gardens (Fig. 112). The numerous editions of guides to the great houses-Stowe, Blenheim, and Wilton-provide a programme for study of development and change in these estates. However, most house guides were published only in single editions that 
are difficult to find and assemble, and some were printed with the express wish "never to be made public" such as Bishop Porteus' A Brief Account of Three Favourite Country Residences: To Which is Added Death, a Poetical Essay of 1808. There are also association copies important for research, such as Horace Walpole's annotated copy of the Stowe Guide (1777). Thomas Sandby's very rare first issuc of Eight Views of Windsor Great Park (ca. 1754) was acquired separately. It is now recognized as a rare record of one of the greatest British estates designed for the Duke of Cumberland by Henry Flitcroft, John Varny and Thomas Sandby in competition with Stowe (Fig. 113).

Other major topographic albums provide subjects of research. Johann Nepomuk Rauch (1804-47), an Austrian active in Switzerland, Rome, and Russia, and known for his landscape paintings, made a portfolio of 17 lithographs (ca. 1835) whose Russian title, written in Cyrillic script on the cover, translates as Views of a Mill Near Moscow Belonging to the Prince Sergei Mikhailovich Golitsyn.... The views also show Frenchinfluenced classical buildings (Fig. 114)-a hospital, a church, the prince's residence, an orangerie, a mill - in a landscape setting emulating that of the British country house. It is also a record of a planned community. The scarcity of such information and of surviving buildings in Moscow from this period increases the interest and value of this album for research, as does its relationship to the other prints and drawings of Russian architecture of the period at the CCA. The Viaggia Pittorico alla Vallombrosa (Florence, 1734) by Antonio Donatio with 36 etched views of the abbey and its land holdings, is one of the rare eighteenth-century books to include depictions of vernacular buildings.

Holdings on Japanese architecture in the Photographs Collection, as well as research documents in building conservation and preservation in all collection areas, are greatly augmented by the acquisition of a collection of 788 government reports ( 838 volumes). Issued by the Ministry of Cultural Affairs and local governments, they document buildings prior to the Meiji Restoration (1868) that were under the supervision of the Japanese government. Compiled by architects, architectural historians, celebrated carpenters, and scholars of Japanese history, the reports analyze in detail construction techniques used in the government-supervised buildings-farms, bridges, colonial buildings, temples, shrines, castles, public and residential buildings. They document in drawings, calotypes and text all restoration undertaken. Since the reports were issued as internal documents with limited distribution, they are not widely held, and large collections are extremely rare even in major libraries documenting Japanese culture in North America.

With the acquisition of the portions dealing with construction from the unique Franklin Institute trade catalogue collection, the $\mathrm{CCA}$ has the foremost collection of trade catalogue literature of any architectural library. It documents building technology and construction methods from the midnineteenth to the mid-twentieth century (Fig. 115).

\section{PERIODICALS}

The Library now maintains more than 700 periodical subscriptions. Several new titles in the fields of art, archaeology, history, and iconography have been added to enrich the interdisciplinary research potential of the collection. Current and retrospective titles published in South America and Asia have been pursued, among others the Argentinean journals Revista de arquitectura (1915-62) (Fig. 116) and Summa (1963 to date), and the Singapore journal Mimar (1981 to date). Since 1984 we have acquired many significant titles that strengthen retrospective holdings. These include the elegant journal Ver Sacrum (1898-1903), which shows the Viennese manifestation of Art Nouveau with its geometrical abstractions, and German and East European Constructivist journals concerned with public housing and social issues between the wars, such as Das neue Frankfurt (1926-33), Red (1927-31) and Blok (1924-26). Issues of the Congrès Internationaux d'Architecture Moderne (СIAM) are dealt with in Dutch and French journals such as De 8 en Opbouw (1932-43) and the ongoing periodical Architecture d'aujourd'hui (1930 to date).

\section{INDIVIDUAL BUILIINGS}

The cca collects notable single sheets or groups for the study of specific individual buildings. A group of drawings and documents by AngeJacques Gabriel (1698-1782) and Jean-FrançoisTherèse Chalgrin (1739-1811) for the Place Louis xv (now the Place de la Concorde), the Hôtel du Garde-Meuble de la Couronne, and the Hôtel de Saint-Florentin were acquired in 1985. Those by Gabriel are for the Hôtel du GardeMeuble de la Couronne, which is located along the northeastern side of the Place Louis $\mathrm{xv}$, and those by Chalgrin are for the Hôtel de Saint-Florentin, which is located facing Gabriel's Hôtel du GardeMeuble. A drawing by a member of Gabriel's office shows the site before the land was expropriated for the Place Louis xv in 1755. Chalgrin's drawings for the Hôtel de Saint-Florentin show an early phase (ca. 1767) when the grand staircase 
was located on the street side, with the court behind, rather than at the front as built (Fig. 117). These drawings are extremely important in marking the beginning of Neo-Classicism in France. The Hôtel de Saint-Florentin was Chalgrin's first major commission and the one in which he, as a member of the younger generation, transcended the architecture of the aging Gabriel.

Drawings at the CCA for buildings by major Chicago architects are key sources for the study of major moments in the history of the most architecturally important city in the United States. Six of John Wellborn Root's Monadnock Block drawings (briefly discussed in Architecture and Its Image $e^{4}$ ), form part of a group of 500 drawings and prints, made from 1884 to 1892 , and must be noted here because of their significance in the history of the skyscraper as a building type and of Chicago itself. The drawings, hitherto unknown, present considerations of style and material, evolving from a Gothic French version to the powerful sheath that was built and, surprisingly, from steel to brick.

The 55 drawings for the T. Eaton Company Store at College and Yonge Streets, Toronto, by the Chicago architect D. H. Burnham and his successors, provide us with new information on this unknown design. The drawings date from 1912, just before Burnham's death, to about 1917. Through them the changes in the development of the building may be studied, both in the articulation of the exterior and in the spatial conventions of the early department store, as Burnham's successors, Graham, Burnham \& Co., continued the design (Fig. 118). The firm's evolving interest in the structural expression of architecture at the turn of the twentieth century can be traced in these drawings; however, by the 1920s the Graham firm - now Graham, Anderson, Probst \& White-showed concern for traditional classicism in the Shedd Aquarium in Chicago. Twenty-seven drawings of 1926-27 in the collection are studies for alternate façade schemes as well as details and section of the aquarium (Fig. 119).

Contemporary concern for classicism, informed by modernism, can be studied at the CCA in the entries of the first and second prize winners of the Mississauga City Hall Competition, 1982. ${ }^{5}$ The work-up drawings and model for the competition, as well as the design and contract drawings by the premiated firm, Jones and Kirkland, were donated to the cca collection. They comprise more than 200 design and development drawings and as-built presentation drawings, more than 200 sheets of working drawings, and 2,000 letter-sized

4 Blau and Kaufman, Architecture and Its Image, 328-30.

5 Blau and Kaufman, Architecture and Its Image, 347-50. ink-on-mylar details, as well as construction photographs (Fig. 120).

Contemporary concerns related to urban conservation, the continuity of history and architecture, and the city, are exemplified in the collections by the drawings for the CCA Building and Gardens themselves, as well as the Alcan Building. Photographs commissioned by the CCA documenting the construction of its building and gardens have also entered the collection. ${ }^{6}$ Alcan's charge to ARCOP Associates was to design a new aluminum-skinned building that would relate to earlier residential buildings to be restored and renovated as part of the new Alcan headquarters. ARCOP's 500 design drawings and 1,500 working drawings were donated to the CCA by the firm and by Alcan.

Continuity in architecture and the traces of site and history take another direction in the work of Peter Eisenman, shown in his University Art Museum, California State University, Long Beach, California. Presentation panels, study models, and drawings at the $\mathrm{CCA}^{7}$ permit analysis of a design process that grows out of a point of departure in philosophical inquiry and the exploration of the physicality of time presented in geological, political, and built-form maps, superimposed by the architect at differing scales. They may be seen as a development "towards an architecture of poetry, fiction and memory" that touches the poetics of John Hejduk's masques in which, through narrative, Hejduk renders a complex statement of the meaning of place and of the human condition. Hejduk's exquisitely precise rendered drawings and free-hand sketches for the Lancaster/Hannover Masque are in the ccA collection (Fig. 121) along with other works by both Eisenman and Hejduk.

\section{ARCHIVES: URBAN DESIGN AND HOUSING AND ARCHITECTS' FONDS}

A high level of research resources in urban design by Canadian architects and planners has been established at the cca through the donation of the archives of Humphrey Carver, of van Ginkel Associates, and of the Milton-Parc project, and with the acquisition of the archives of Wells Coates.

The Humphrey Carver Archives consists of files documenting the activities of this architect, who played a seminal role in the development of housing and urban affairs as a public concern in Canada. The files, which cover a period from 1930 to

6 Larry Richards, Canadian Centre for Architecture: Buildings and Gardens (Montréal, 1989).

7 Blau and Kaufman, Architecture and Its Image, 356-57. 
1987, pertain to Carver's involvement in initiating courses on planning as well as rescarch on housing issues at the School of Architecture and the School of Social Work at the University of Toronto and his years as founding Chairman of the Canada Mortgage and Housing Corporation Research Committee and Advisory Group, and as a proponent of federal government support of low-rental housing.

The archives of van Ginkel Associates includes planning projects from 1955 to 1980 in Canada, the United States, Jamaica, and Malaysia. Among airport studies are those for the Montréal International Airport, and those in Caracas and Jamaica. Important among the urban studies are those made in 1957-62 of vehicular circulation in downtown Montréal, which led to further studies from 1961 to 1964 that stopped the planned demolition of Old Montréal, as well as studies for the location of Expo 67. Studies in northern regions include those for the Churchill River diversion project in Manitoba, on the Mackenzie Valley pipeline and for Arctic Gas. They are inquiries into the impact of development on communities and those who build in the North (Fig. 122).

The Milton-Parc Archive provides a major set of documents on the Canadian Mortgage and Housing Administration's support of low-income housing in the 1980s. It covers the history of protest against the destruction, of the eventual rehabilitation of this downtown Montréal neighbourhood from 1970 to 1989, and of the largest notfor-profit cooperative housing renovation undertaken in Canada. The Milton-Parc Archive was donated to the CCA by the Société d'amélioration $d u$ Milton-Parc, a private organization responsible for coordinating renovation of the area (Fig. 123).

In addition to individual buildings and planned projects, discussed above, major fonds or archives deposited at the CCA in the last five years include the donation of the Fonds of Gérin-Lajoie/ Leblanc, consisting of records of buildings designed for the use of the Government of Canada between 1968 and 1980; the extensive Archives of Ross \& Maclonald and successor firms, which cover major buildings across Canada from 1903 to 1959; the donation by the Sociéte de développement de Montréal of the Archives of Stelco's complex along the Lachine Canal, which includes industrial buildings dating from 1901 to 1984; and the donation by John C. Parkin of his Archives of 1971-87 with some earlier projects going back to 1945, including his own house of 1953. The Parkin Archive documents major public buildings in the Maritimes and public and private buildings in Ontario, including his proposals in the early 1970s for the never-built Met- ropolitan Toronto Convention Centre, and drawings of the firm's submission to the 1976 competition for the National Gallery of Canada.

To this listing must be added some discussion of the successive donations of the Arthur Erickson Archives and of the Wells Coates Archive. The latter was acquired with the help of repatriation funds of the Federal Government. Wells Coates (1895-1958), a Canadian born in Japan and educated in British Columbia, was a pioneer of the International Style in England in the 1930s, and an influential contributor to the development of the "Modern Movement" and to urban planning in Canada in the 1940s and 1950s. He was actively involved in such important architectural organizations as the Modern Architectural Research Group (MARS), Unit One, and the Congrès Internationaux de l'architecture moderne (CIAM). Coates was in contact with the leading architectural and intellectual figures of his day. The Wells Coates Archive includes correspondence with Europeans such as Le Corbusier, Walter Gropius, William Lescaze, Raymond Loewy, and Siegfried Giedion, as well as with Arthur Erickson, Geoffrey Massey and John B. Parkin in Canada.

The Welis Coates Archive is a rich source, for future study, of mostly unpublished material on the Modern movement and on Wells Coates' own life. It begins with a diary written at age 13 (Fig. 124) and includes material on his well-known reinforced concrete apartments at Lawn Road in London (1932-34) and on his wide interest in industrial design: advanced radio and television sets, sailboats and aircraft, mass-production housing, and an elevated monorail for a mass rapid transit system for British Columbia (1957).

Arthur Erickson donated 381 drawings, mostly his own conceptual sketches, and 20 photographs. The drawings concern 29 major projects between 1973 and 1987, including the Museum of Anthropology at the University of British Columbia, Vancouver, California Plaza, Los Angeles, Roy Thomson Hall, Toronto (Fig. 125), the Canadian Chancery, Washington, and 14 private residences.

\section{PHOTOGRAPHS}

As is the case with all the other collections, the material in the Photographs Collection acquired in the past five years is rich and varied, with a complex relationship to the existing collection as well as a high quality of individual works. The principal direction of the collection described in Les débuts/The First Five Years, 1979-1984 has continued in the last half decade, and individual holdings have been strengthened through the careful 
acquisition of key images, both single prints and albums. This policy applies especially to holdings of works by major photographers, such as Edouard Baldus, Gustave Le Gray, Charles Nègre, Linnaeus Tripe, Robert Macpherson, Felice Beato, Carleton Watkins, Eugène Atget, Frederick Evans, Paul Strand, Berenice Abbott, Werner Mantz, August Sander, Clarence Laughlin, Josef Sudek, and Aaron Siskind. Groups of photographs of the works of architects include an important series by Lucien Hervé of selected buildings by Le Corbusier and F. V. Bingham's modest Architectural Views of Winnipeg, Comprising Colleges, Schools, Business Blocks, Terraces, Villa Designs (1883), all designed and built by Barber and Barber.

The most significant new development has been in the area of contemporary photographyimportant bodies of photographs by Bernd and Hilla Becher, Klaus Frahm, Lee Friedlander, Eikoh Hosoe, Yasuhiro Ishimoto, Richard Pare, Thomas Struth, and Laura Volkerding. The collection has also become increasingly involved with commissioning documentary campaigns for existing architectural work: The Lachine Canal, 1985-86 (Clara Gutsche and David Miller), the ccA Buildings and Gardens, 1987 (Clara Gutsche, Laura Volkerding, Gabor Szilasi, Richard Pare, Geoffrey James), Ernest Cormier's Carrefour StDenis, 1988, and his Université de Montréal, 1989- (Gabor Szilasi), the Olmsted Landscape, 1989 (Geoffrey James, Lee Friedlander, Bob Burley).

A major individual work of the nineteenth century must be noted - the early 1840s daguerreotype of the View of the Renaissance Well at the Château de Châtillon at Châtillon-sur-Loing by Edmond Becquerel (1820-91). This daguerreotype (Fig. 126) is highly significant in the history of the medium and with regard to its iconography. Becquerel was a physicist. He was president of the Académie des Sciences in the 1880s and a member of a distinguished family of physicists. Because of his work on photo-chemically induced electricity and on spectography applied to photography, Becquerel was introduced to Daguerre in the late 1830s to help him with his experiments. Until now, it was not known that Becquerel also made daguerreotypes. His carefully composed image of the well on the terrace of the Orangerie of the Château de Châtillon was taken at the property, which was adjacent to his own in Châtillonsur-Loing. This daguerreotype had remained there until very recently, with the only other known daguerreotype by Becquerel. The well is attributed to the designer-sculptor, Jean Goujon (ca. 1510-ca. 1568). The structure is compelling both formally and in its symbolic iconographic programme, which includes draped piers, a dodecahedron sundial and allusions to the Protestant-Catholic struggles of the sixteenth century.

Research on architecture in India, in European languages at least, is wanting. Benjamin Rowland, professor at Harvard and a leading historian in the field of Indian art, acknowledged that even a general discussion was limited by the photographs of monuments available to him in $1953 .{ }^{8}$ Recent research into photographic collections on the subject indicates the rarity of existing nineteenthcentury photographic prints and negatives. In this context, the very major acquisition of seven of the nine albums of the British Army Captain Linnaeus Tripe (1822-1902) is all the more important as a research source at the CCA. All the albums are dated 1858 and some are accompanied by a descriptive text. The group comprises 77 albumenized salt prints and albumen prints. The work forms a survey of the temples, palaces and military forts of the presidency of Madras, taken at Madura, Tanjore, Trivady, Seringham and Poodoocottah (Fig. 127). This group of images adds to 42 photographs by Tripe already in the collection, a number of which are from Governor General Lord Dalhousie's 1855 mission to Ava (Burma). Some of Tripe's images were engraved and used as illustrations of the publications of the 1860 s by the architectural historian James Fergusson. ${ }^{9}$

Attention must also be drawn to two major individual images of the twentieth century: Wall Street, New York, 1915, by Paul Strand (1890-1976) and Industrial Landscape, 1929, by Albert RengerPatzsch (1887-1966). Wall Street, New York, 1915 (Fig. 128) is an intellectual creation. It was not intended by Strand to lead to an understanding of the building depicted - the Morgan Guaranty Trust Company - but to distill fact into an evocation of meaning. A portion of the building is isolated and transformed by Strand into a brooding, potent symbol of the oppression of workers by capitalist institutions. In this regard it is significant that the image was made two years before the Russian Revolution and well over a decade before the great Wall Street Crash in which the Morgan Bank was to play a key role. The CCA print is unique. The printing process was complex and resulted in the only print of Wall Street, New York, 1915 signed by Strand (Fig. 128).

8 Benjamin Rowland, The Art and Architecture of India: Buddhist, Hindu, Jain (Harmondsworth, England, 1956), 153.

9 Janet Dewan, "Linnaeus Tripe Photographer of British India, 1854-1870," in Linnaeus Tripe Photographer of British India, 1854-1870 (Toronto, Art Gallery of Ontario, 1 November 1986-11 January 1987), 22, note 63. 
Richard Pare has written about RengerPatzsch's Industrial Landscape (Fig. 129) as follows:

Albert Renger-Patzsch's photograph, made up of only the simplest industrial forms, is a powerful demonstration of the illusions of photography. It is a carefully calculated image that, by its juxtaposition of large and small elements, and near and far in space, creates an inner tension that is in tune with the subject matter.... The very sparseness of the resources at the disposal of the photographer gives this picture a rigour that is an effective symbol of the machine age in $1929 .{ }^{10}$

The positive world view of industrialization in Germany expressed by Renger-Patzsch is dialectically opposed by the epistemology inherent in Clara Gutsche's image of a decaying industrial structure (Fig. 130). The structure is one of more than 200 photographs of the Lachine Canal area in Montréal made by David Miller and Clara Gutsche, that were commissioned by the CCA before buildings were demolished or - in the case of the 1840 locks and later bridges - transformed for reuse, in order to have a coherent, intelligent visual record of the historically most important industrial site in Canada.

\section{CONCLUSION}

In this brief report, it has been my purpose to give a view of the nature of the collections of the cCA. I have placed primary emphasis on the assembly of coherent groups of documents that provide subject matter for sustained research into the history of architecture. A single drawing, print or photograph may be the subject of extensive analysis. However, the set of images-design alternatives and working drawings, views of a city, garden, or building, comparative compilations of building types or parts - is intrinsic to architectural representation. And as Eve Blau has written in her introduction to Architecture and Its Image, ". . . the full significance of architectural imagery can best be recovered within the serial context of the group."11 It should also be noted that the group, like the individual print, drawing or photograph, is for the most part a fragment of an archive. Forming an architectural collection is often an act of reassembling fragments.

Because of the richness and depth of materials collected around a focus on architecture, a multitude of interconnections exists across collection types. Many of these connections are made and implied in this article. Those revealed in subsequent articles, whether they be interpretations of events or intuitions, are the result of our ability to compare original groups of works and to trace

10 See notes in the cca's object file, Photography Collection. 11 Blau and Kaufman, Architecture and Its Image, 12. the development of various modes of representation in different media.

I have chosen the images illustrated here to give as broad a view as possible of our holdings by complementing those accompanying other articles in this issue and those in other publications by or on the CCA (see bibliography). The images presented here have been made for the most exalted and the most ordinary purposes. They have also been made to resolve issues of the built world. They are intended to show that works in various media may and do range from the modest book on the most humble building represented, to stellar examples of both subject and rendering.

Finally, it must be stated that established authenticity, high quality, and good condition are fundamental to all the objects in the collections at the CCA. Poor quality impedes comprehension. The objects in the collections are conserved and viewed in optimal conditions, so that the scholar and the visitor may study together -in depth and with continuity-drawings, prints and books from the fifteenth century until today as well as photographs of the nineteenth and twentieth centuries. The ccA's collection records the history of the built world throughout the history of the art.

\section{ACKNOWI.EDGMENTS}

This report is based on research notes prepared for acquisition by members of the departments of Prints \& Drawings, Photographs, Archives and the Library, and by the Research Curator.

\section{BIBLIOGRAPHY}

\section{CCA PLBLICATIONS}

Bcrgdoll, Barry, dir., Le Panthéon: symbole des révolutions (Paris : Centre Canadien d'Architecture/Les Editions A. \& J. Picard/Caisse nationale des monuments historiques et des sites, 1989).

Blau, Eve, et Edward Kaufman, dir., L'Architecture et son Image: quatre siècles de représentation architecturale: oeuvres tirées des collections du Centre Canadien d'Architecture (Montréal: Centre Canadien d'Architecturc/ Canadian Centre for Architecture, 1989).

Blau, Eve, and Edward Kaufman, eds., Architecture and Its Image: Four Centuries of Architectural Representation: Works from the Collection of the Canadian Cientre for Architecture (Montréal: Centre Canadien d'Architecture/Canadian Centre lor Architecture, 1989).

Centre Canadien d'Architecture: les débuts, 1979-1984/ Canadian Cientre for Architecture: The First Iive Years, 1979-1984 (Montréal: Centre Canadien d'Architecture/Canadian Centre for Architecture, 1988).

L.eggat, Portia, comp., A Union List of Architectural Records in Canadian Public Collections/Catalogue collectif de recherche documentaire sur l'architecture provenant de collections publiques canadiennes. Canadian Architec- 
tural Records Survey/Recherche documentaire sur l'architecture canadienne (Montréal : Centre Canadien d'Architecture/Canadian Centre for Architecture, 1983).

Lcrup, Iars, Planned Assaults: The Nofamily House, Love/ House, Texas Zero, Postscript by Peter Eisenman (Montréal: Centre Canadien d'Architccture/ Canaidian (entre for Architecture, 1987).

Pare, Richard, ed., Photographie et architecture: 1839-1939. Introduction par Phyllis Lambert. Catalogue par Catherine Evans Inbusch et Marjoric Munstcrberg (Montréal : Centre Canadien d'Architecture/Canadian Centre for Architecture/Lditions du Meridien; Liège: Pierre Mardaga, 1984).

Pare, Richard, ed., Pholography and Architecture: 1839-1939, Introduction by Phyllis Lambert, Catalog by Catherine Evans Inbusch and Marjorie Munsterberg (Montréal: Centre Canadien d'Architecture/ Canadian Centre for Architecture; New York: Callaway Editions, 1982).

Richards, Larry, ed., Centre Canadien d'Architecturel Canadian Centre for Architecture: Building and Gardens, Introduction by Phyllis Lambert (Montréal: Centre Canadian d'Architecture/Canadian Centre for Architecture, 1989).

Richards, Larry, ed., Centre Canadien d'Architecturel Canadian Centre for Architecture: Buildings and Fardens,
Introduction by Phyllis Lambert (Montréal: Celltre Canadian d'Architecture/Canadian Centre for Architecture, 1989).

Wagg, Susan, Ernest Isbell Barott architecte: une introduction/Ernest Isbell Barott Architect: An Introduction (Montréal: Centre Canadian d'Architecture/ Canadian Centre for Architccture, 1985).

\section{PUBIICATIONS RELATING TO CCA} COLLECIIONS

Blaser, Worner, Architecture and Nature: The Work of Alfred Caldwell/Aichitecture et nature: l'oeuvre d'Alfred Calduell/Architektur und Natur: Das Werk von Alfred Caldwell (Basel: Birkhäuser Verlag, 1984).

Hambourg, Serge, Mills and Factories of New England. Essays by Noel Perrin and Kenneth Breisch, Captions by Kenncth Breisch (New York: Harry N. Abrams, in association with the Hood Museum of Art, Dartmouth College, 1988).

Pare, Richard, ed., Court IIouse, A Photographic Document, Conceived and directed by Phyllis Lambert, 'The Writers of Court House, Phyllis Lambert et al., The Photographers of Court House, Harold Allen et al. (New York: Horizon Press, 1978).

Centre Canadien d'Architecturel Canadian Cientre for Architecture 1920, rue Baile

Montréal, Québec H3H2S6 


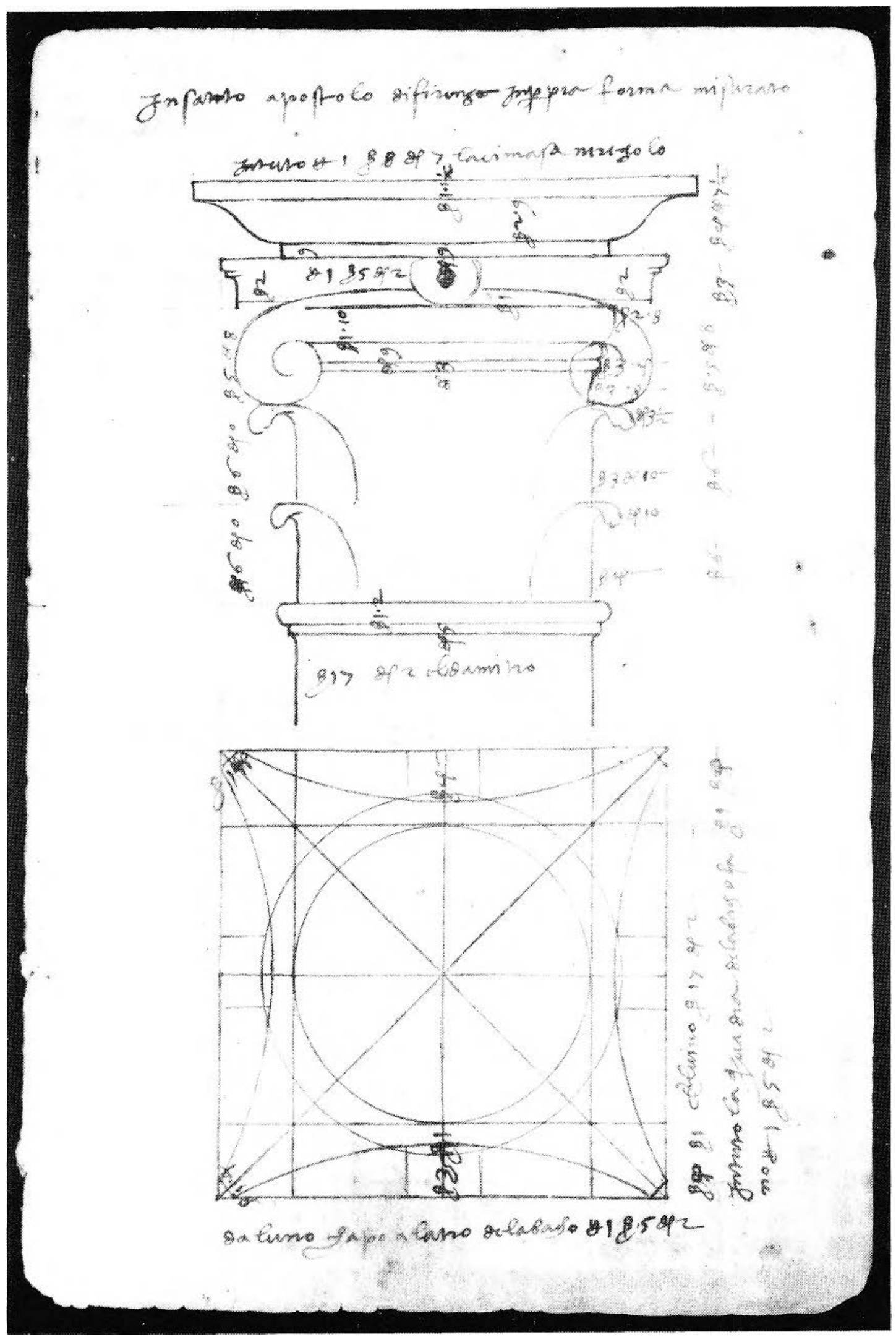

ligl:re 105. Simone di Tomaso del Pollaiuolo, called Il Cronaca, Florence, 1457-1508. Plan and Elezation of an Ionic: Capital from the (hurch of Santi Apostoli, Florence, pen and brown ink over stylus and red chalk underdrawing on laid paper, about 1484-1500, $22 \times 14.5 \mathrm{~cm}$. DR 1985:0671r, Collection Centre Canadicn d'Architecture/Canadian Centre for Architecture, Montréal. 


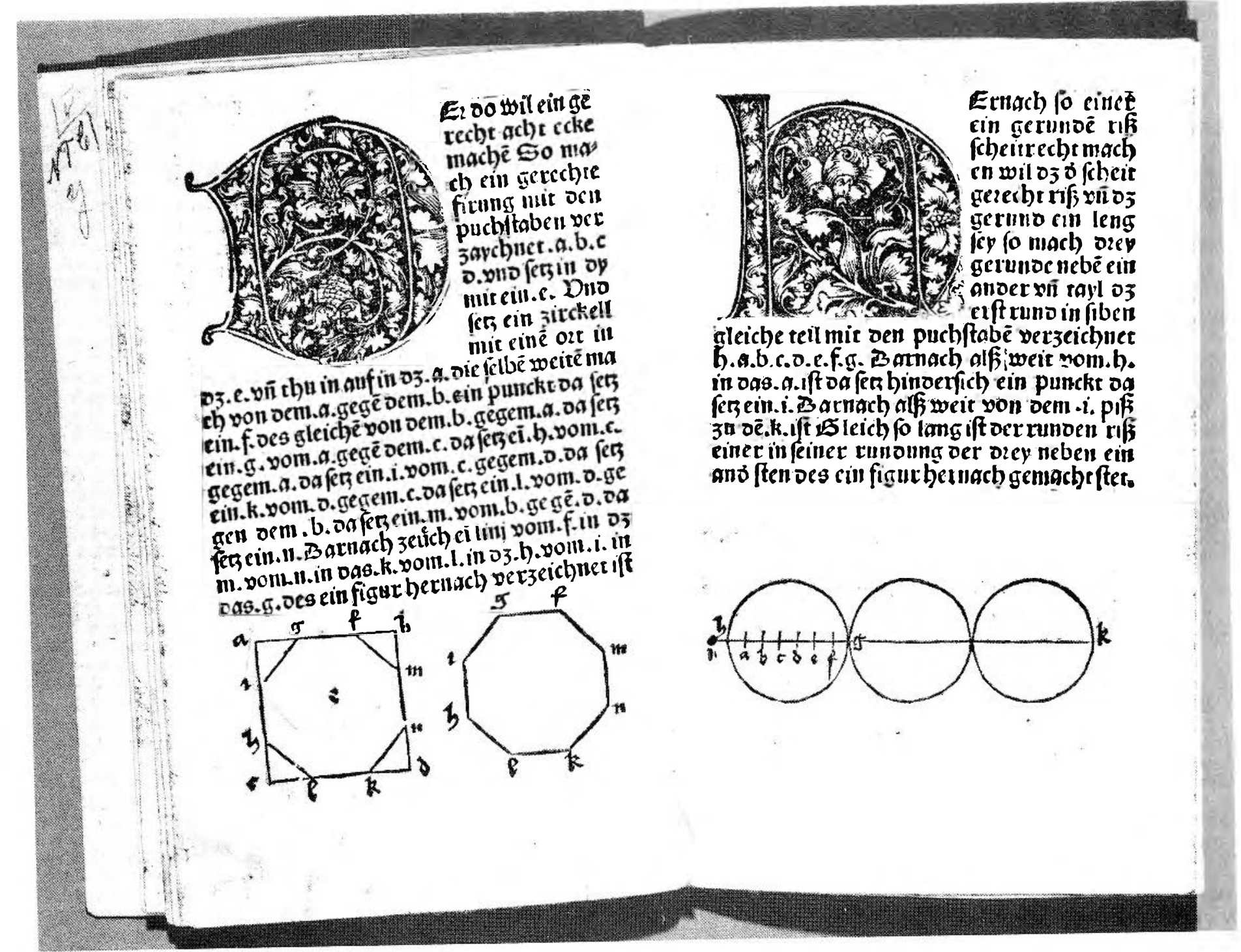

Ficit:k 106 Mathäus Roritzer, Lipper Palatinate, about 1435-Regensberg, 1495, Cieometria deutsch, Nuremberg, Pere

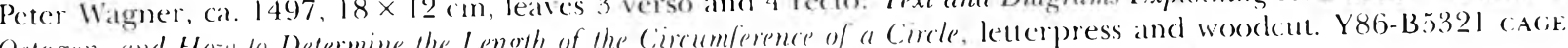

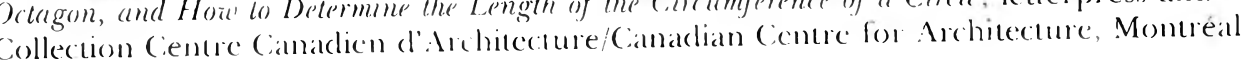




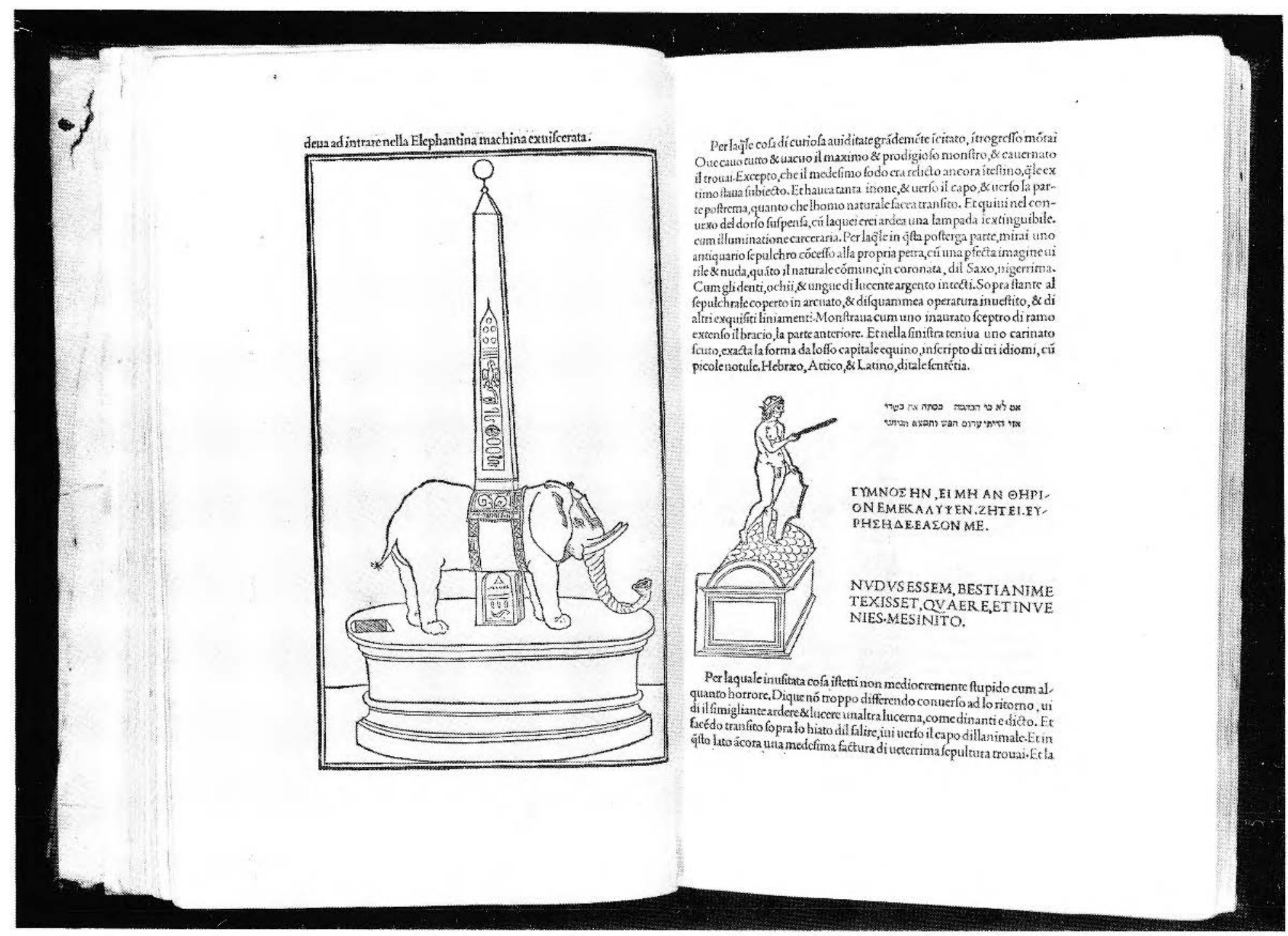

Figtre 107. Attributed to Francesco Colonna, Iord of Palestrina, Rome, about 1453-al)out 1538, Hypmerotomar hin

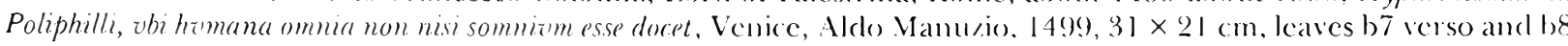

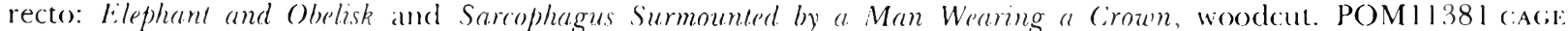
Collection Centre Canadien d'Architccture/Cantadian (ientre for Architecture. Montréal. 


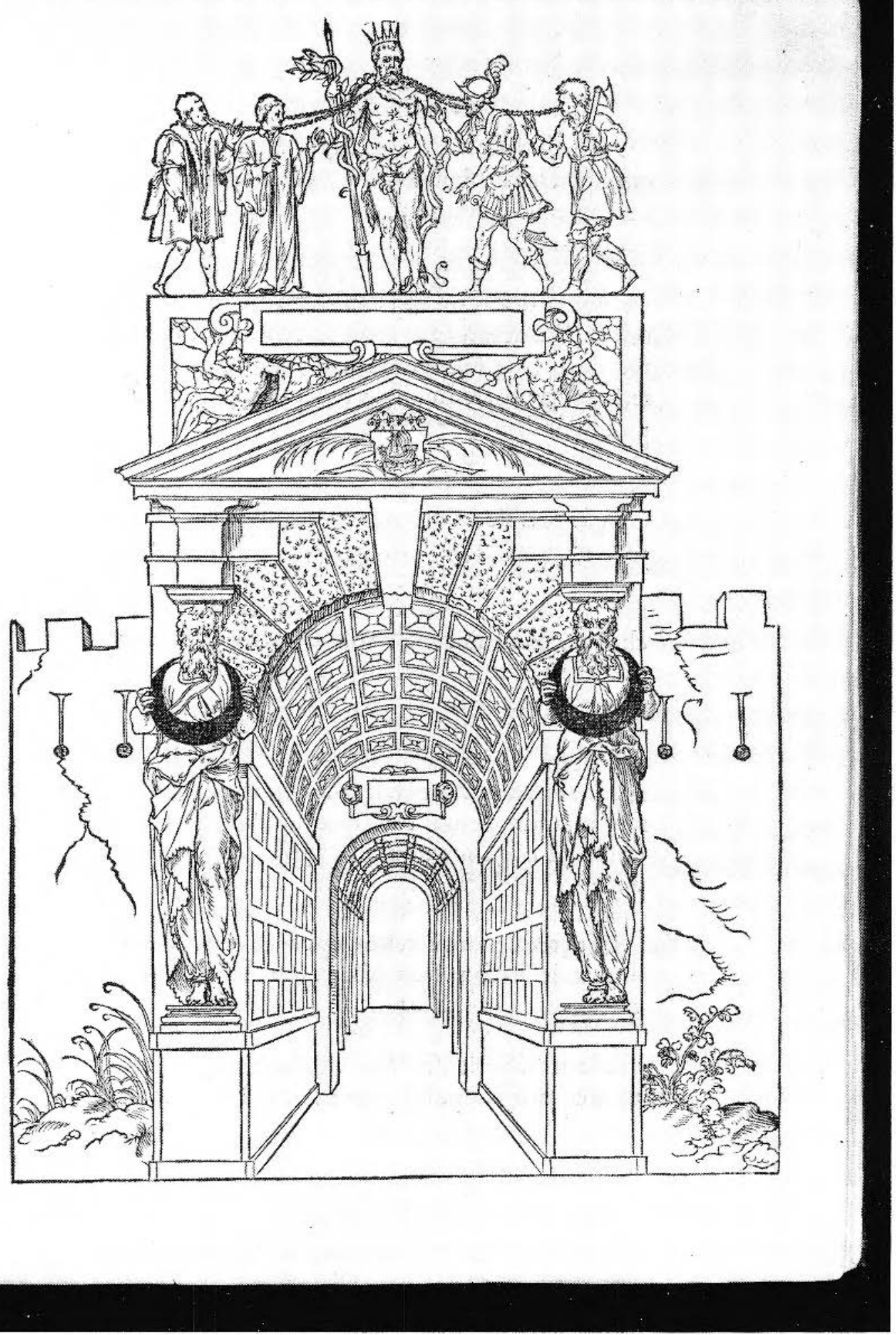

Figire. 108. C'est l'ordre qui a este tenv a la novvelle et ioyeuse entrée, que le treshault, tresexcellent, É trespuissant Prince, le Roy treschrestien Henri deuzieme de ce nom, à faicte en sa bonne ville et cité de Paris, capitale de son royaume, le sezieme iour de iuin M.D.XIIX, Paris, Jean Dallier, 1549, $24 \times 27 \mathrm{~cm}$, leaf a iv recto: Triumphal Arch with Francis I Depicted as l'Hercule Gaulois, arch designed by Jean Goujon, iconography devised by Jean Martin, woodcut. 86-B1872 rerrs, Collection Centre Canadien d'Architecture/Canadian Centre for Architecture, Montréal. 


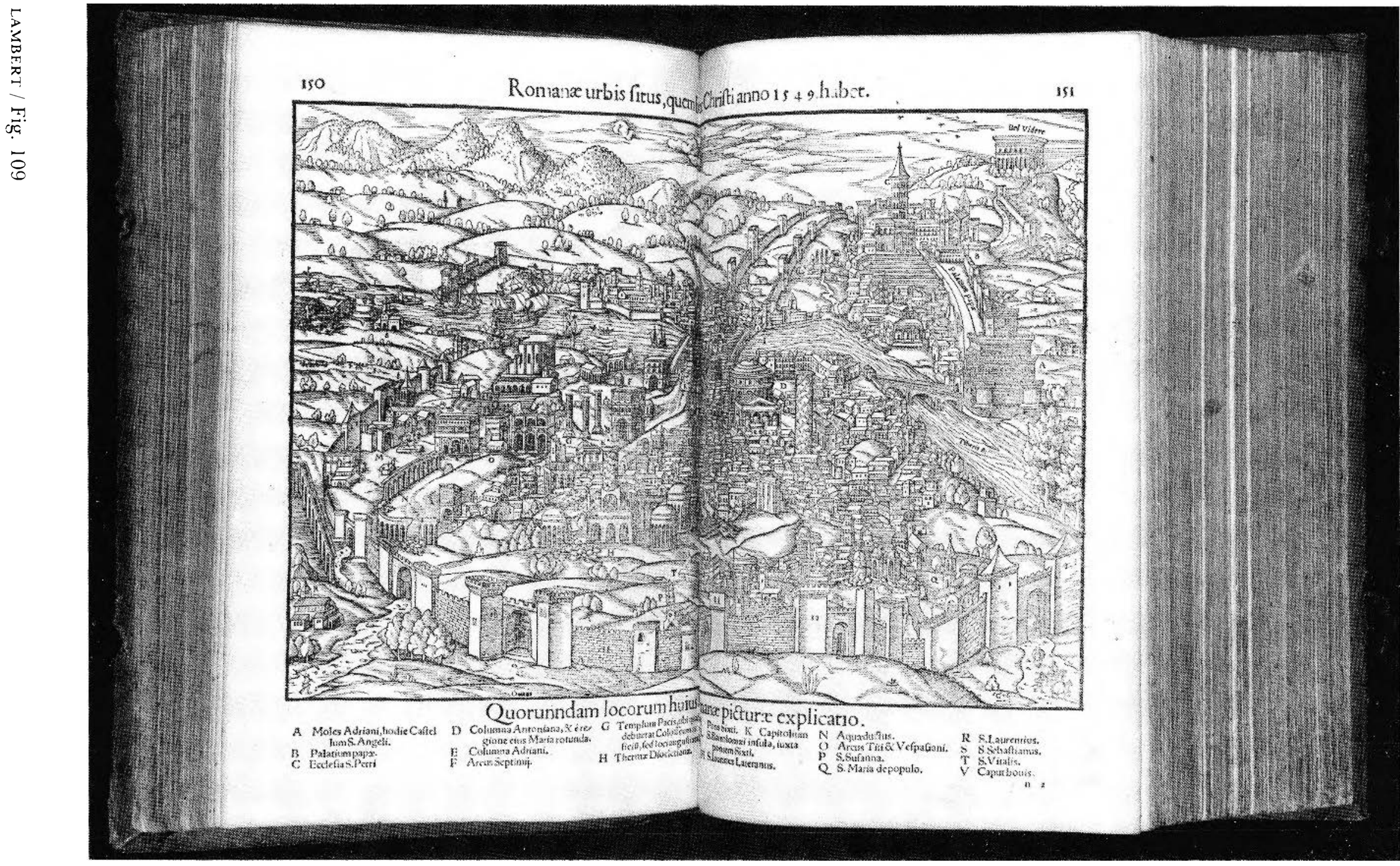

Figure: 109. Selbastian Münstcr, Rhenish Palatinate, Ingelheim 1489-Basel 1552, Cosmographiae uninuersalis lib. VI, Basel, Heinrich Petric, 1554 latin edition, $32 \times 22 \mathrm{~cm}$, pages 150-51: View of the City of Rome in the Year 1549, woodcut. M86-BI6686 cacie, Collection Centre Canadien d'Archilecture/Canadian Centre for Architecturc, Montrial. 


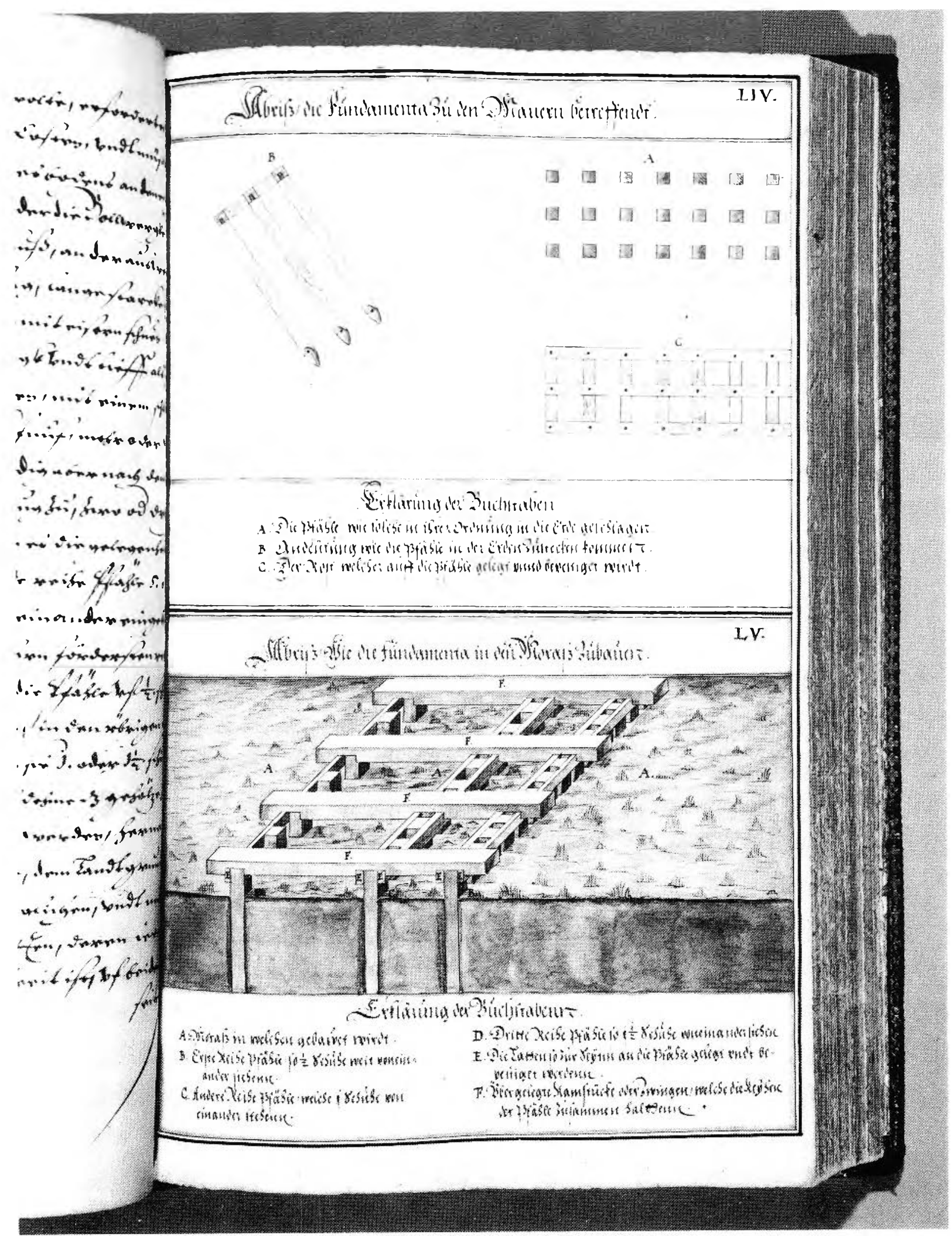

Ficier: 110. Johamn Melchior, Ritter von Schwalbach, Ilesse, Giessen 1581-1)resden 1653, author, and Wilhelm Dilich, Hesse, Wabern abou1 1571-Dresden 1650, designer and draftsman, Perspective View and Details of the Wooden Foundations Intended to Support. Masonry Bastions, pen and black ink, green, brown, pink, and blue watercolour on laid paper, about $1627,31 \times 18.8 \mathrm{~cm}$, plates 1.Iv and iv from Kurtzer und grundlicher Bericht... DR 1986:0761:0831, Collection Centre Canadien d'Architecture/Canadian Centre for Architecture, Montréal. 


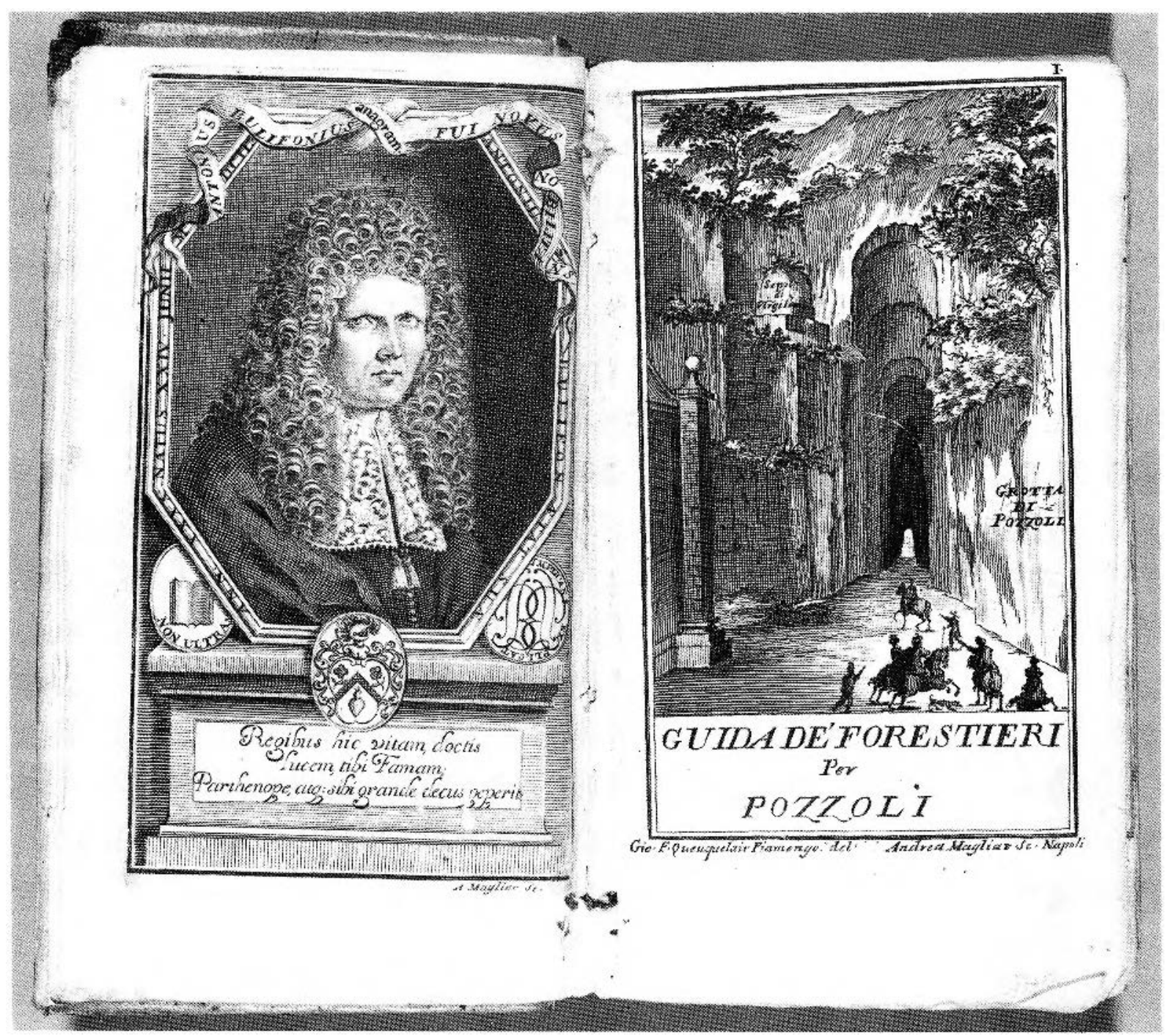

Figere 111. Pompeo Sarnclli, Polignano 1649-Naples 1724. Guida de' forestierilla guide des étrangers, Naples, Giuscppe Roselli, 1697, edition in Italian and French. French translation by Antonio Bulifon, $15 \times 9 \mathrm{~cm}$. frontispiece and plate 1: Portrait of the Translator, Antonio Bulifon, cngraved by Andrea Magliar, and Illustrated Title Page, with View of the Grotto on Pozzuoli, etched by Andrea Magliar, after a drawing by (Giovanni lirancesco Queucuelair. ITY B35. N1776, Collection Centre Canadion d'Architecture/Canadian Centre for Architecture, Montréal. 


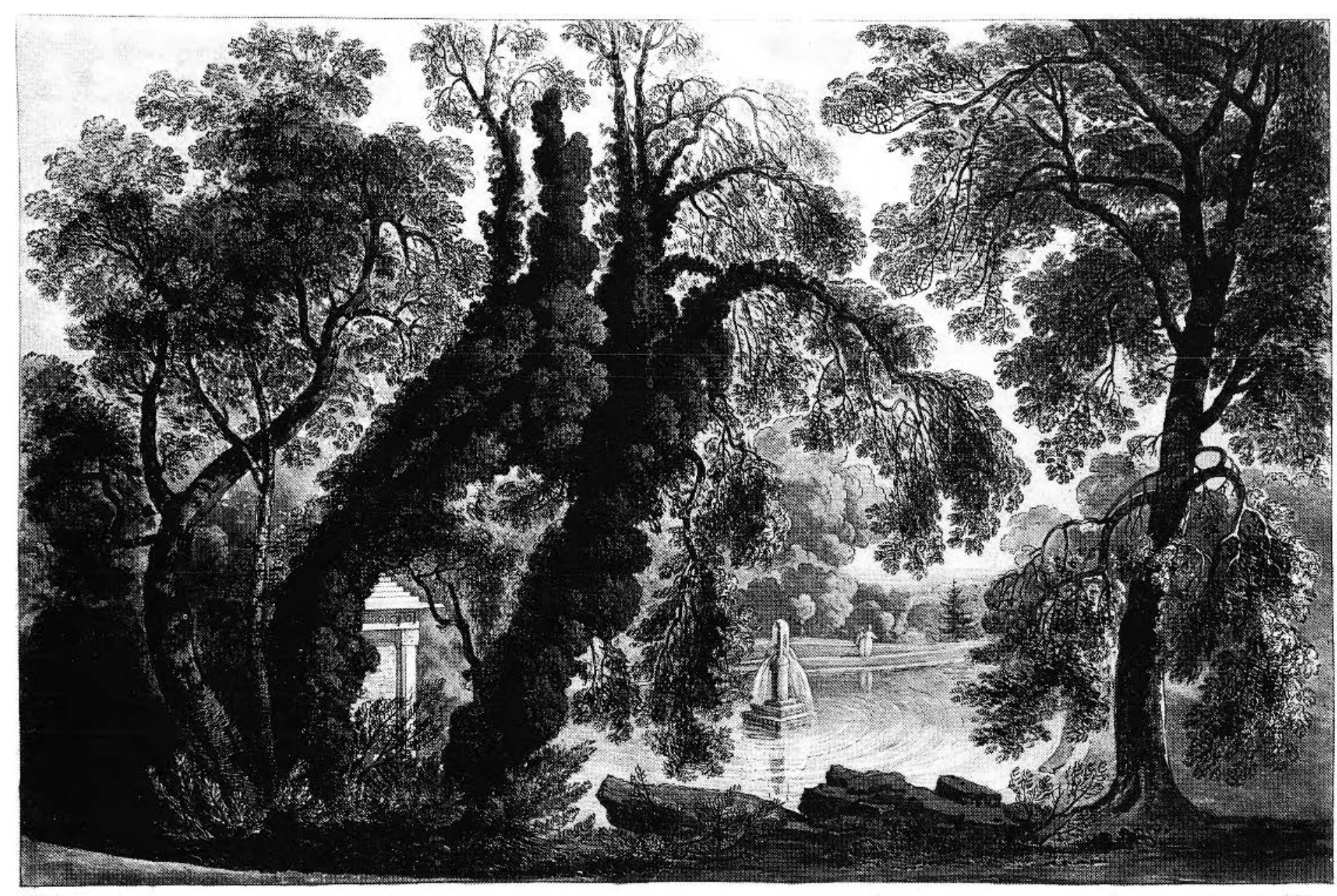

Figure 112. Views of Sezincote House and (Frounds, the Seat of Sir Charles Corkerell, London, ca. 1820, $42 \times 5.5 \mathrm{~cm}$, plate 7: Vieu' from the North, of the Fountain of Maha Dao and Part of the Temple of Suyah, drawn and etched by John Vartin, engraved by Frederic Christian Lewis, aquatint printed in scpia. M87-B2206.53 unk RIs, Collection Centre (ianadicn d'Architcoture/Canadian Centre for Architecture, Montréal. 


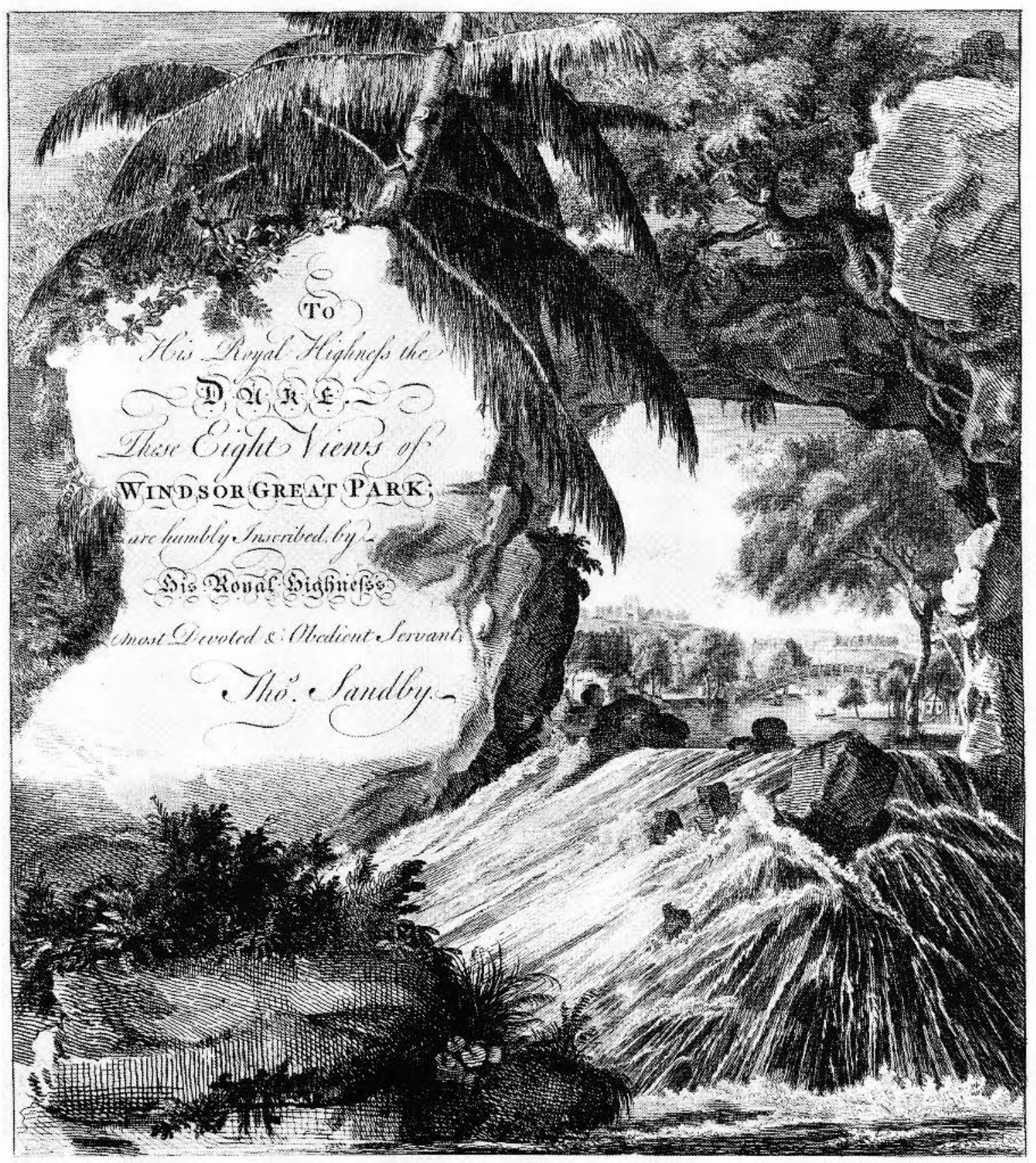

Figure 113. Unknown cingraver, after Thomas Sandby, architect, England, Nottingham 1721-Windsor 1798, Dedicatory Frontispiece to the Album: Eight Views of Windsor Great Park, engraving on wove paper, about 1754 , $65.5 \times 49.0 \mathrm{~cm}$. DR1987:0106:001, Collection Centre Canadien d'Architecturc/Canadian Centre for Architecture, Montréal. 


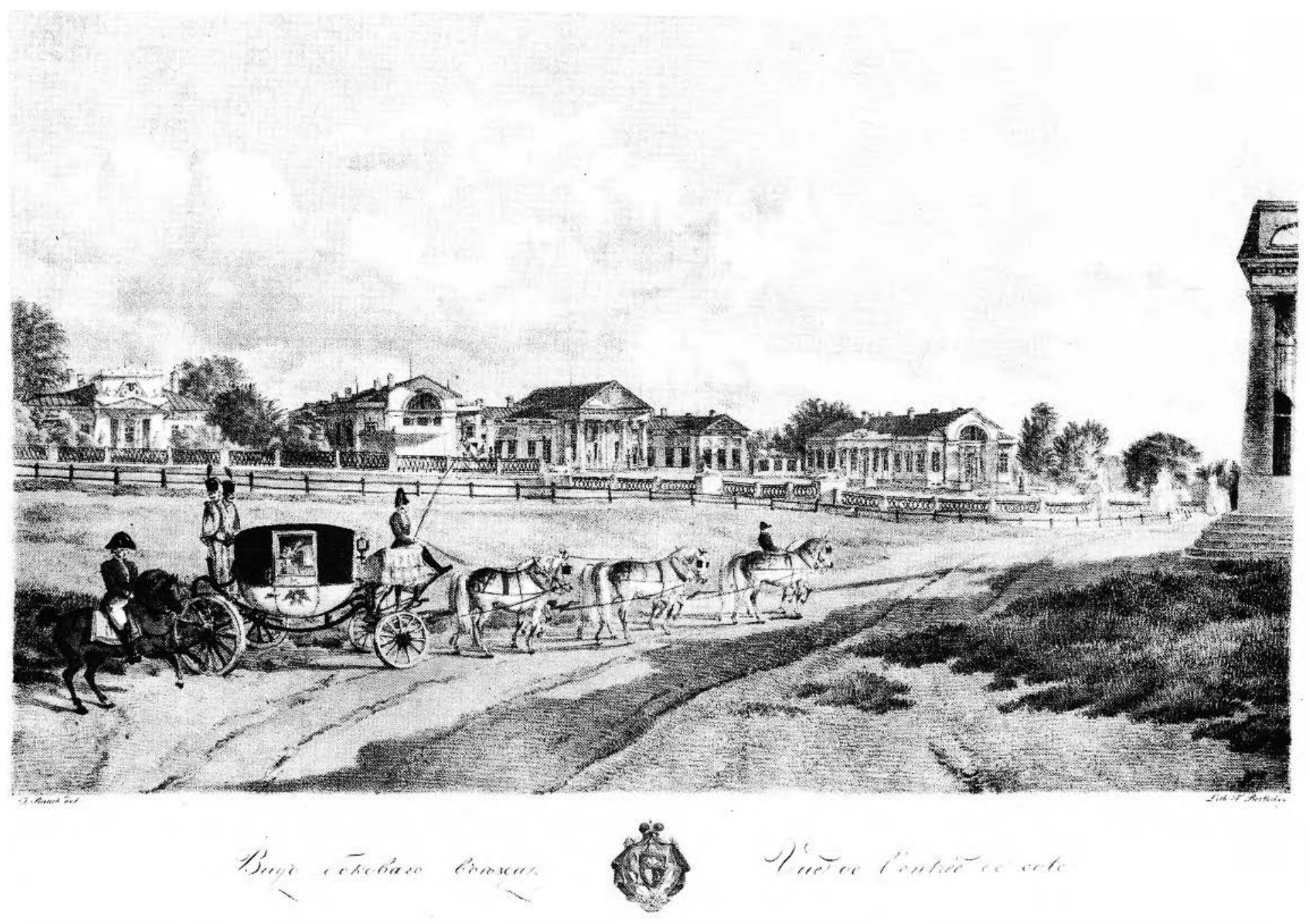

Frgitrf. 114. Johamn Nepomuk Rauch, Austria, Vienna, 1804-Rome. 1847, active Swityerland and Russia, and F. Bartholds. lithographer, Virat of the Side Entrance to the Golitsyn Fstate athich Comprises a Hospital, Mill, Orangerie, Church, Stables and Farm. hand-coloured lithograph on wove paper, about 1830-40.47.5 $\times 60.7 \mathrm{~cm}$, from a portfolio of 17 views of the estate outside Woscow belonging to Prince Sergei Mikhailovich Golitsyn. DR 1986:0475:015, Collection Centre Canadien d'Architecture/Canadian Centre for Architecture. Montréal. 

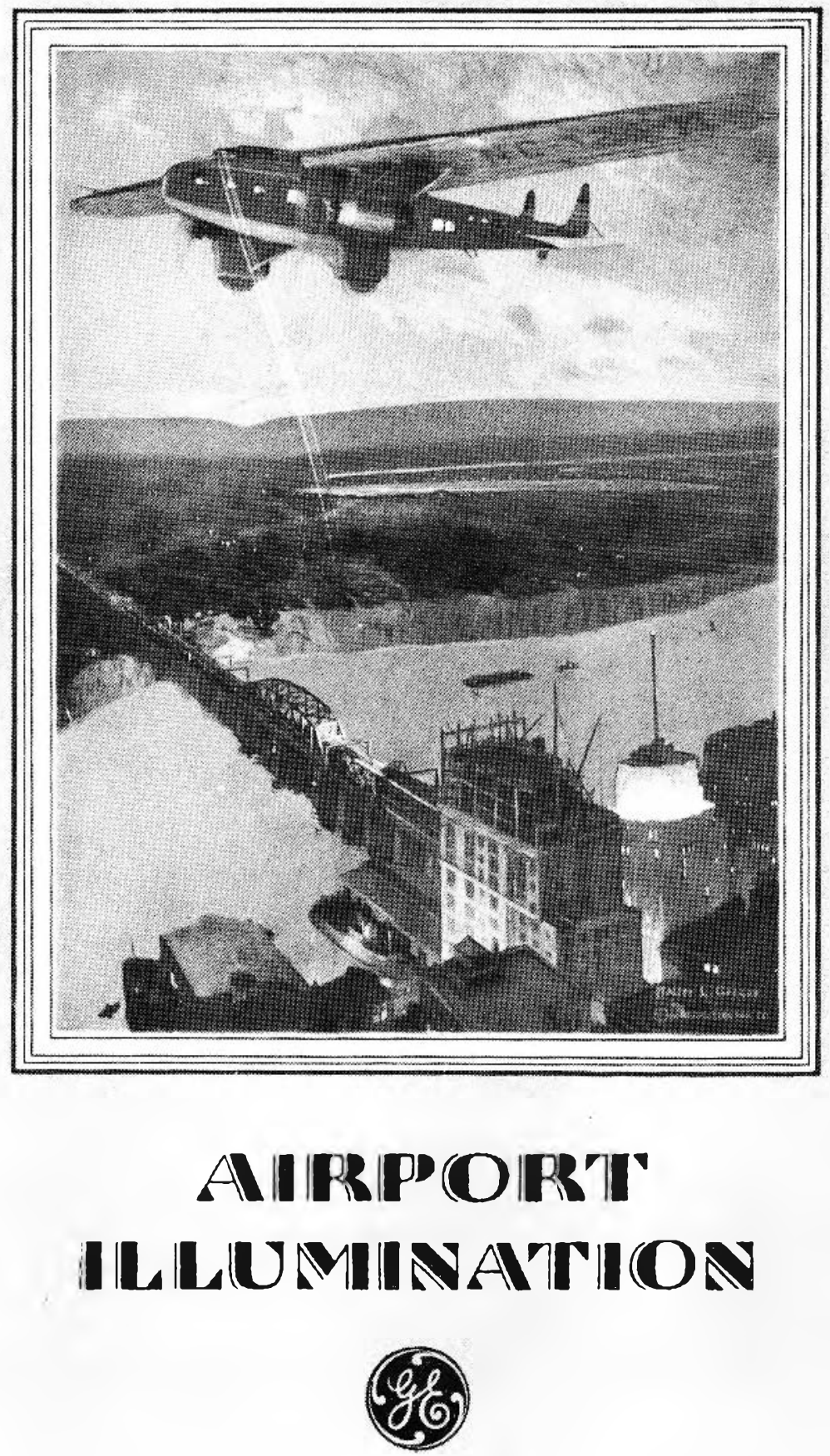

Ficiurt 115. (ieneral Electric Company, Airport Illumination. 23-page illustrated trade brochure, describing the company's airport lighting equipment, Schenectady, New York. (ieneral Llectric (ompany, May 1930. $28 \times 21$ (m. ref, Collection Contre Cimadien d'Architecture/Cianadian Centre for Architcoure, Montréal. 


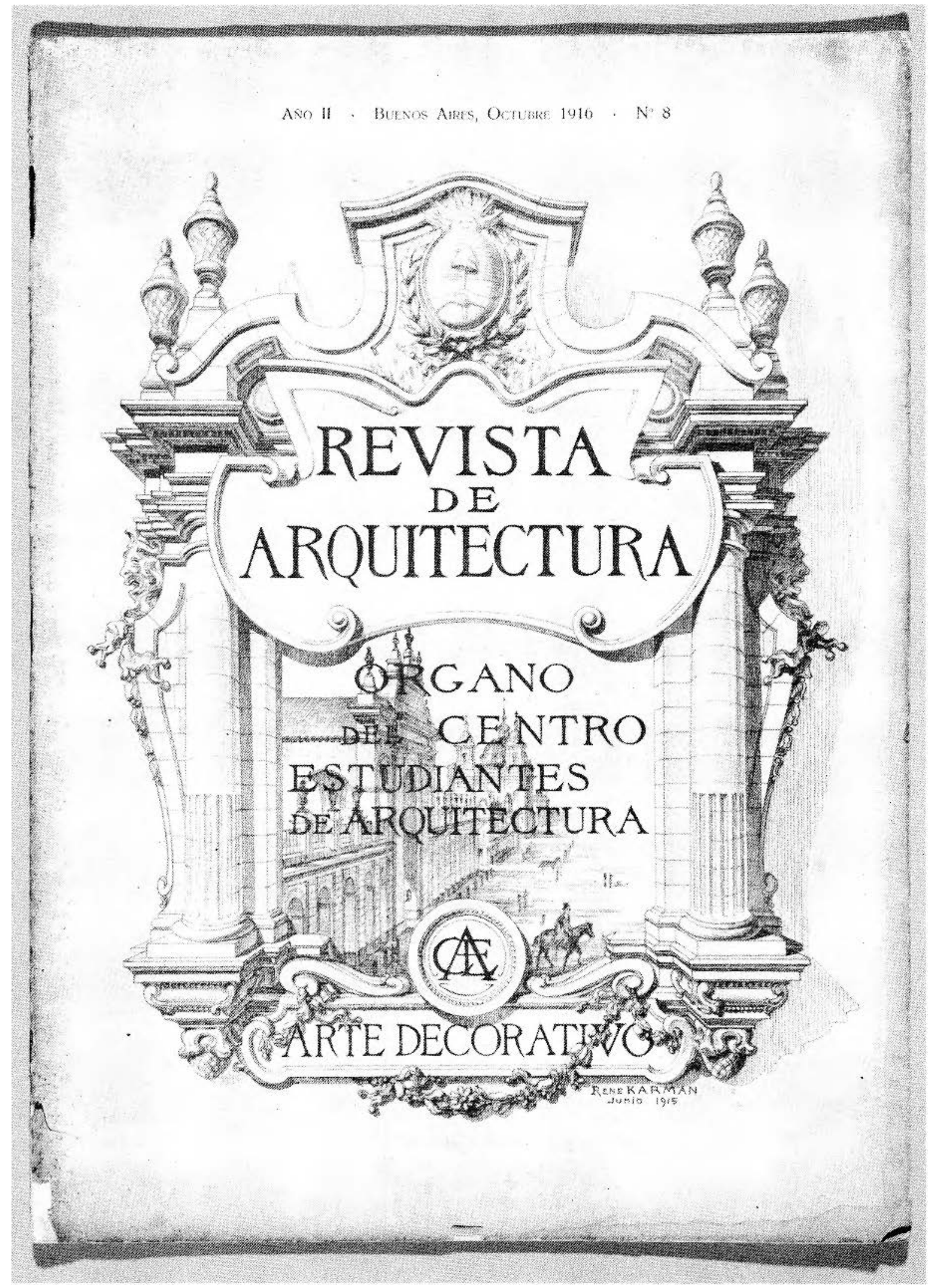

Figurf 116. Revista de arquitectura, Bucnos Aircs, Volume II, no. 8, 1916, cover, designed by Rene Karman, June 1915, $32 \times 24 \mathrm{~cm}$. W.R47612, Collection Centre Canadien d'Architecture/Canadian Contre for Architecture, Montréal. 


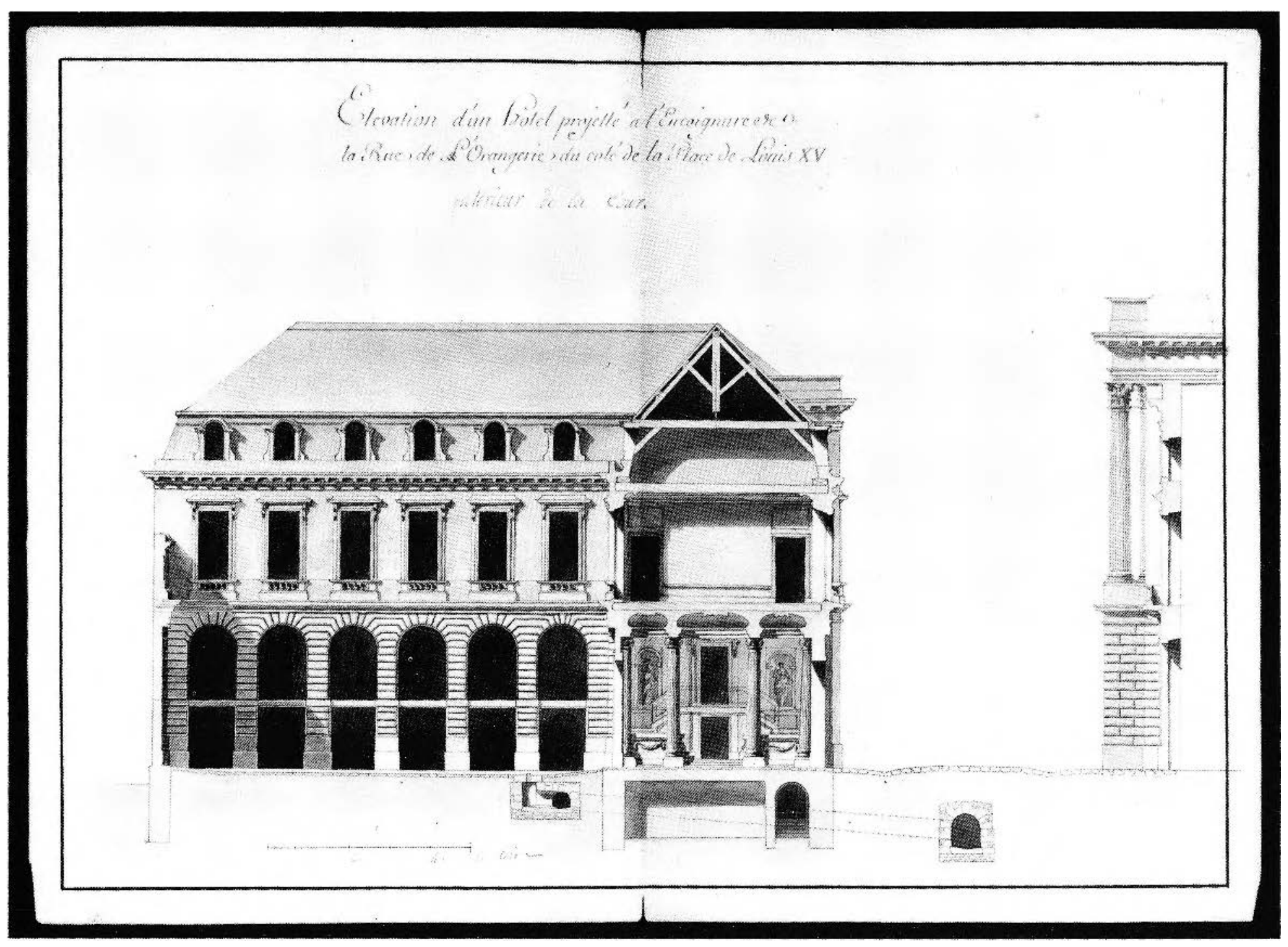

FIGU'RE 117. Jean-François-Thćrèse Chalgrin, Francc, Paris, 1739-1811, Cross-section and Elevation of the Courtyard of the Hôtel de Saint-Florentin and Section of the Hôtel du Garde-Meuble, Paris, pen and black ink, grey, pink, and beige watercolour over graphite on laid paper, about 1767, 36.2 $\times 49.9 \mathrm{~cm}$. DR 1985:(0460r, Collection Centrc Canadien d'Architecture/Canadian Centrc for Archilecture, Monıréal. 


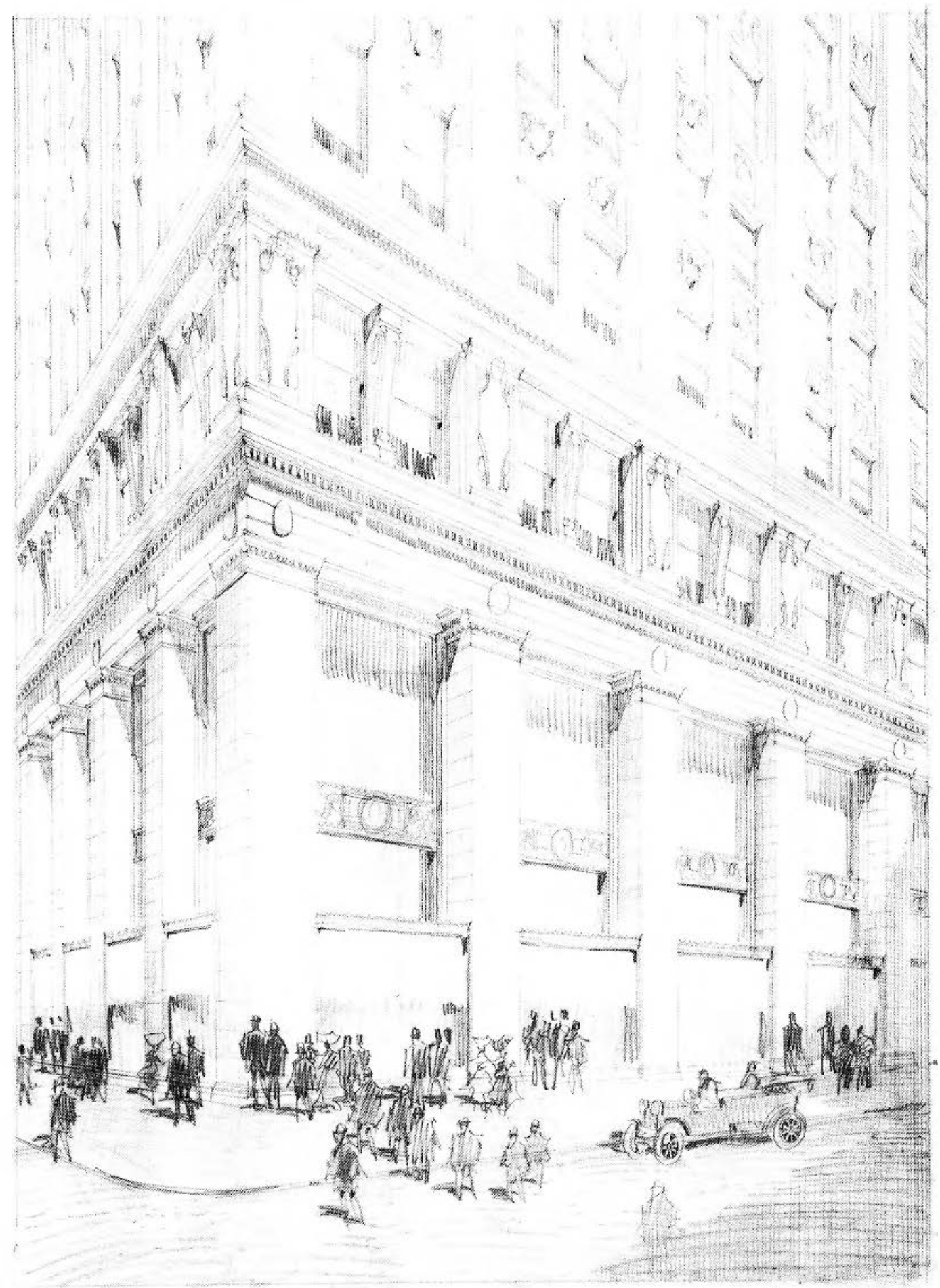

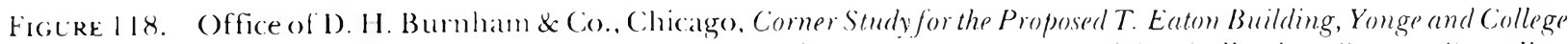
Strests, Toromen, graphite on tracing paper, 1912-13,115.3 $88.4 \mathrm{~cm}$. DR 1985:(0741, Collection Centre Canadien d'Architcoure Cianadian (entre for Architecture, Montréal. 


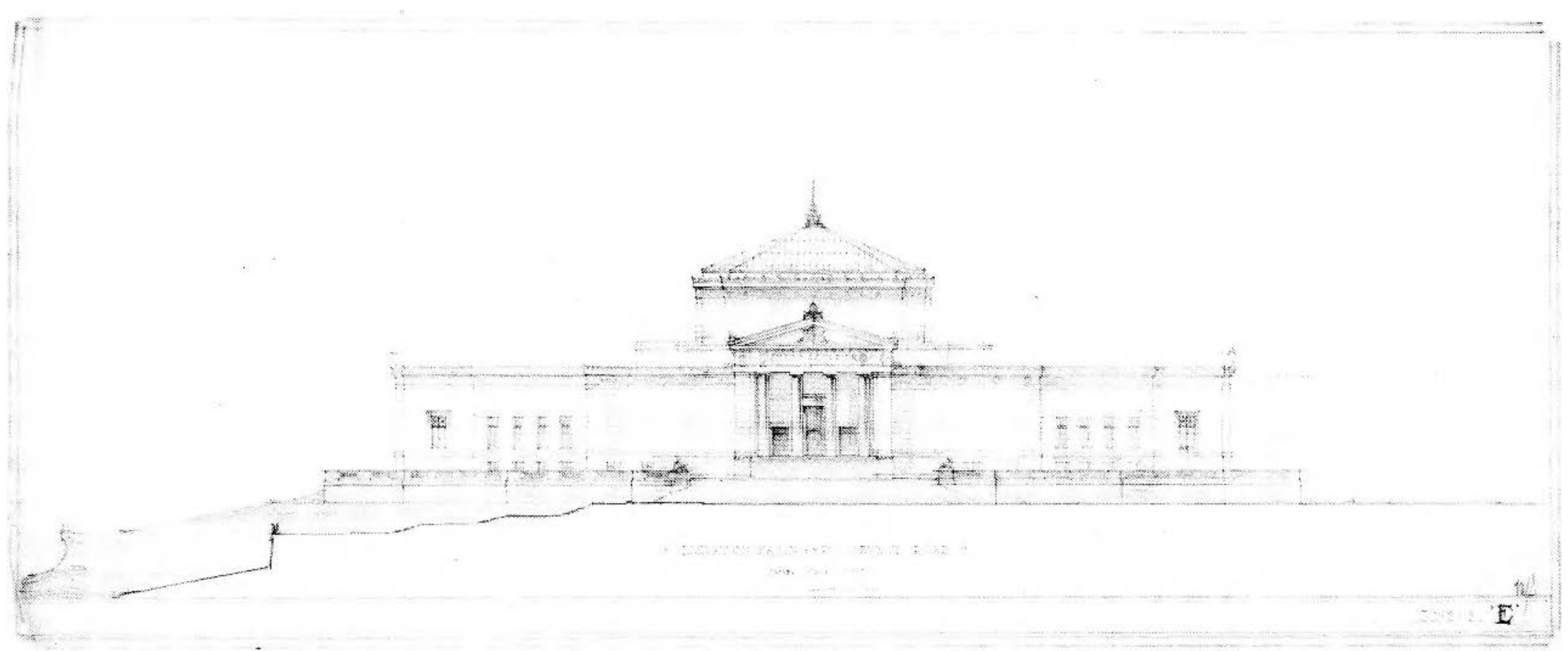

Fotere: 119. M. Schiavoni, draftsman, for Graham, Anderson, Probst \& White, architects, (Shicago. Study of the Elevation lacing Roosevelt Road-Scheme L for the Proposed John G. Shedd Aquarizum, Chicago, graphite, green, red, blue. purple, and yollow coloured pencil, about 1924-29, 35.9) $88.5 \mathrm{~cm}$. DR 1986:0420, Collection Centre Canadien d'Architecume/Canadian (icntre for Architcoure. Montréal. 


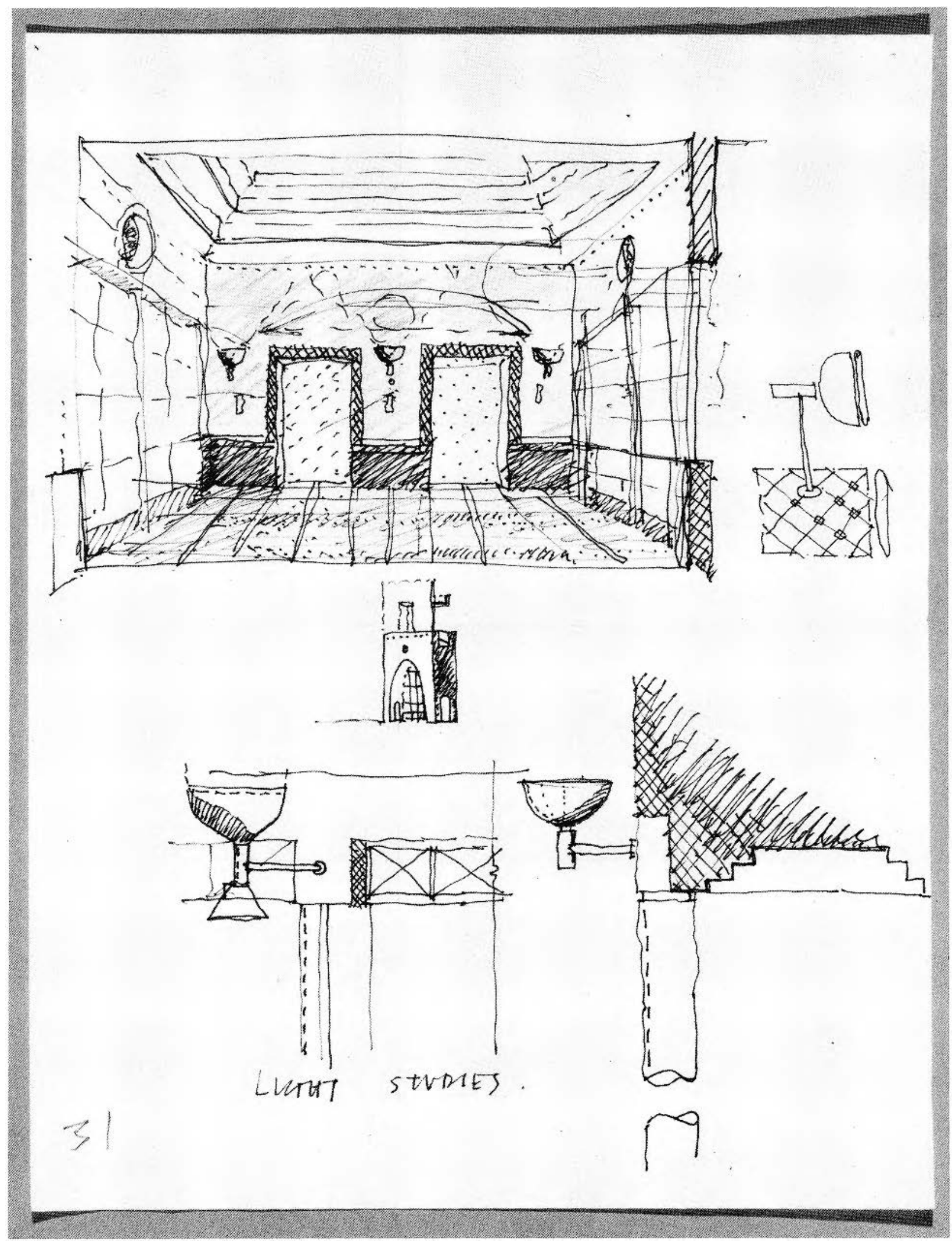

Figure 120. Office of Jones and Kirkland Architects, Toronto, Study Sketches for Finishes and Lighting in Public, Elevator Lobby, Mississauga City Hall, Mississauga, Ontario, black and blue felt pen on bond paper, undated, after 1982, $27.5 \times 21.3 \mathrm{~cm} .24$ ARc: ()01N, Collection Centre Canadien d'Architecture/Canadian ('entre for Architecture, Montréal. 


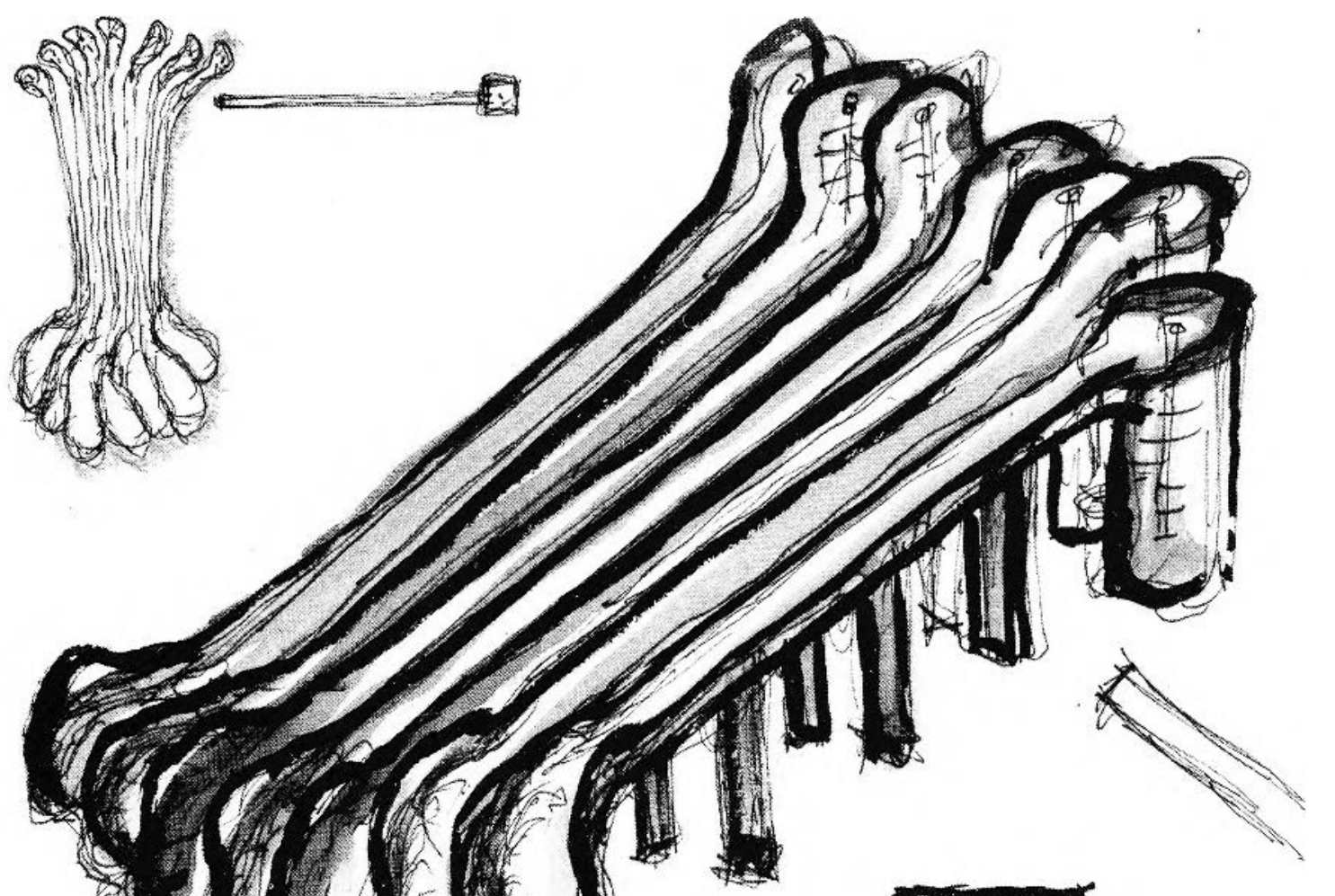

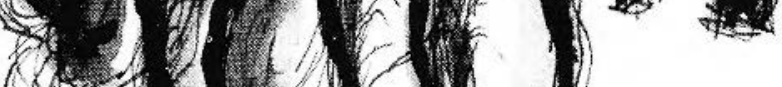

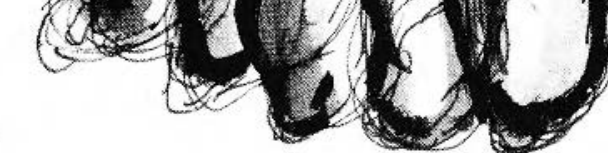
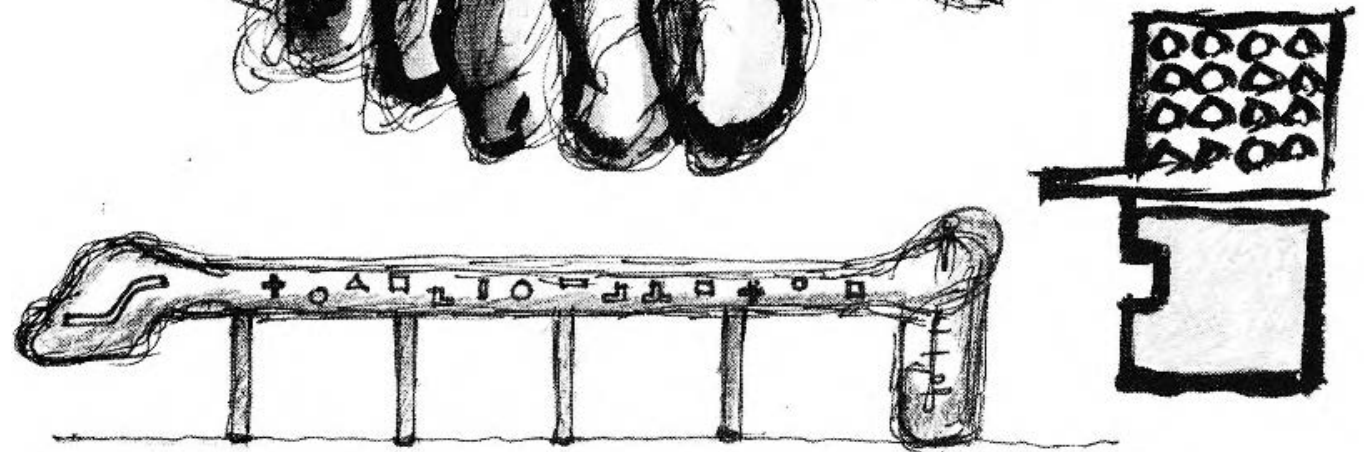

Figicr. 121. John Hejduk, United States, New York (ity, 1929)- , Drauings for the Lancasler/Hanover Masque: "The" Hotel-No. 3," blue marker, green ink wash, green, blue, white and brown crayon on grey rice paper, 1983 , 


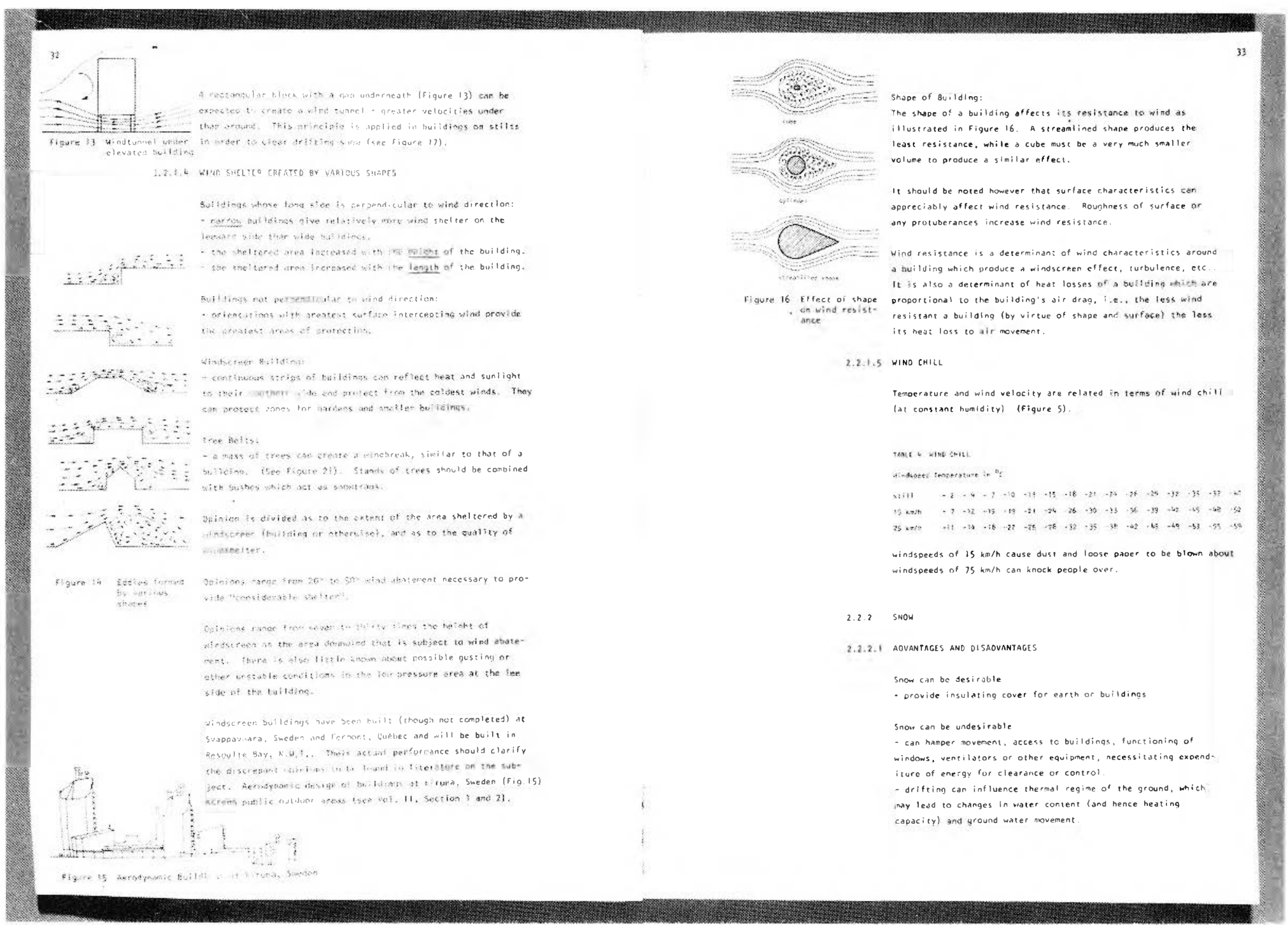

Figi Re 122. Van Ginkel Associates I.td.. Foronto, for Canadian Arctic Gas Study limited, and Gull (Oil Cannada L.mited. Imperial ()il Limited, Shell Canada Limited, Building in the North: Responding to the Eintironmont in Canada,

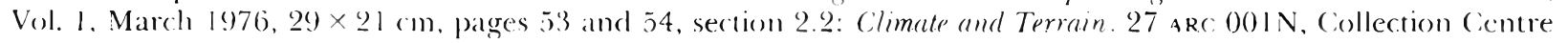
Canadien d'Architecture/canadian Centre for Architecture, Montréal. 


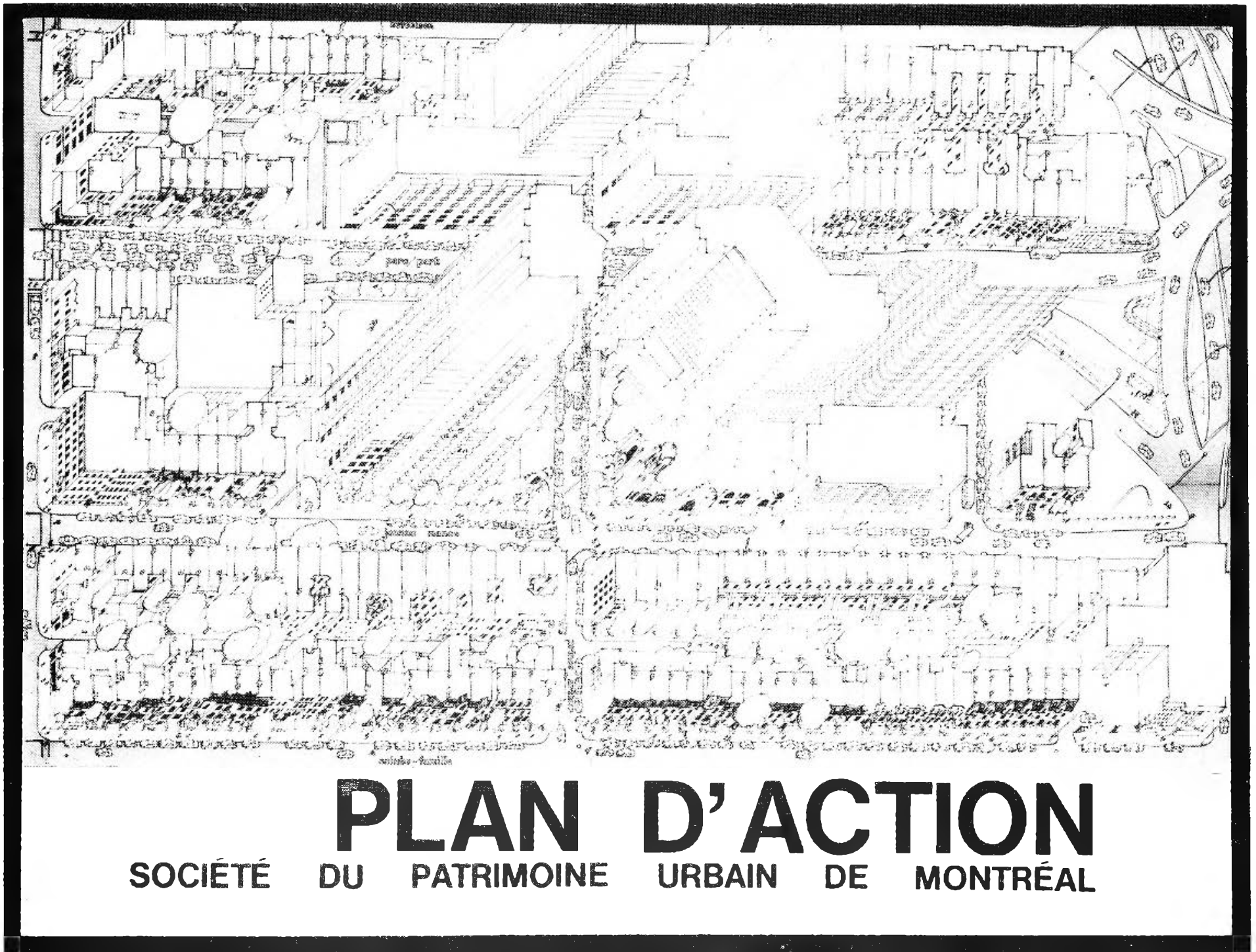

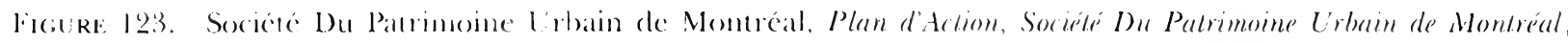

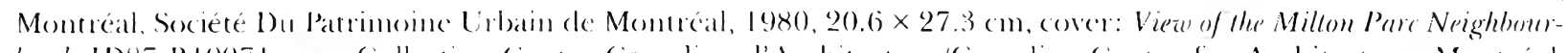

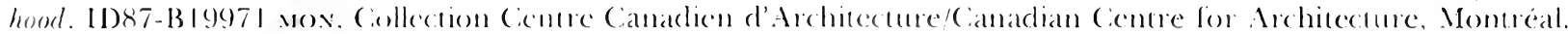




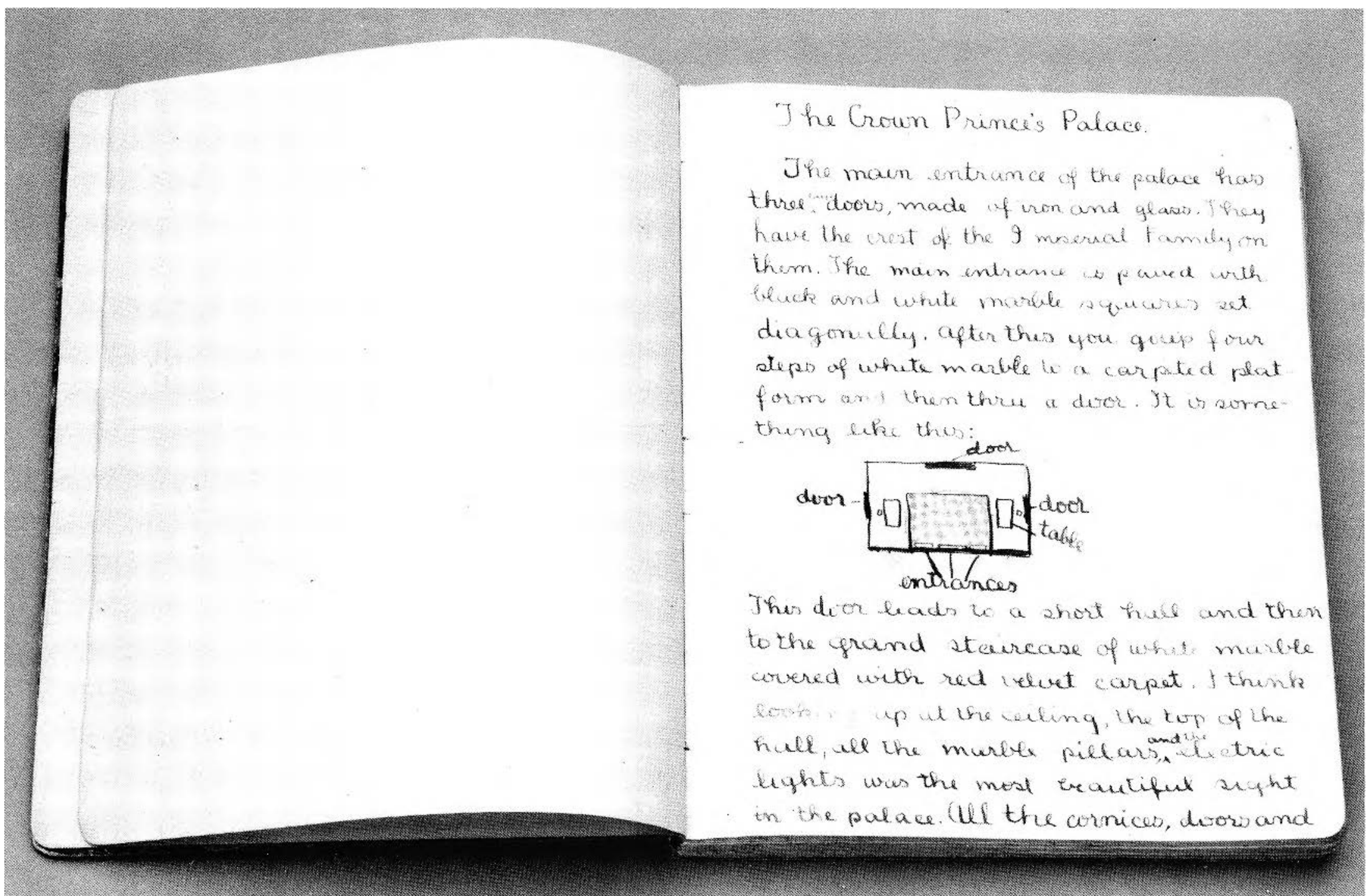

Figure 124. Wells Wintemute Coates, Canada, Tokyo 1895-Vancouver 1958, Sights and Experiences in Japan, 1908-1909, 20.5 $\times 16 \mathrm{~cm}$, leaf 3 recto: First Page of The Crown Prince's Palace, the first of eight descriptions in a manuscript notebook written at age 13, black ink and pencil on squared paper. $30 \mathrm{ARC} 001 \mathrm{~N}$, Collection Centre Canadien d'Architecture/Canadian Centre for Architecture, Montréal. Copyright () Laura Cohn 1989. 

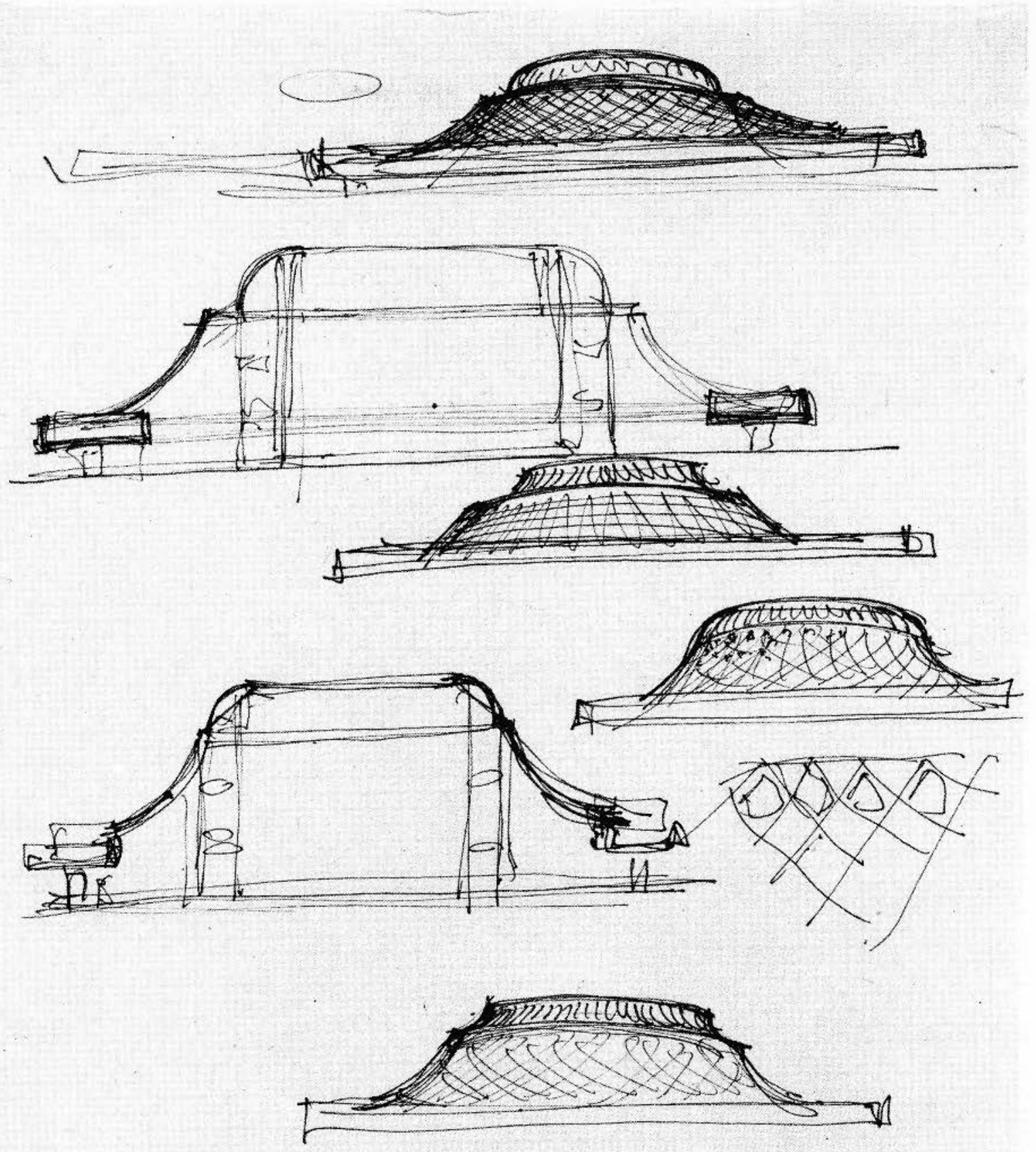

Figure 125. Arthur Erickson, Cianada, Vancouver 1924- , Conceptual Perspective Sketches, with Sectional Studies and Roof Detail, Roy Thomson Hall, Downtoun West, Toronto, felt-tip pen on yellow manila paper, about 1976, building constructed 1976-1982, $28 \times 21 \mathrm{~cm} .22$ ARC 040N, Collection Centre Canadien d'Architecture/Canadian Centre for Architecture, Montréal. 


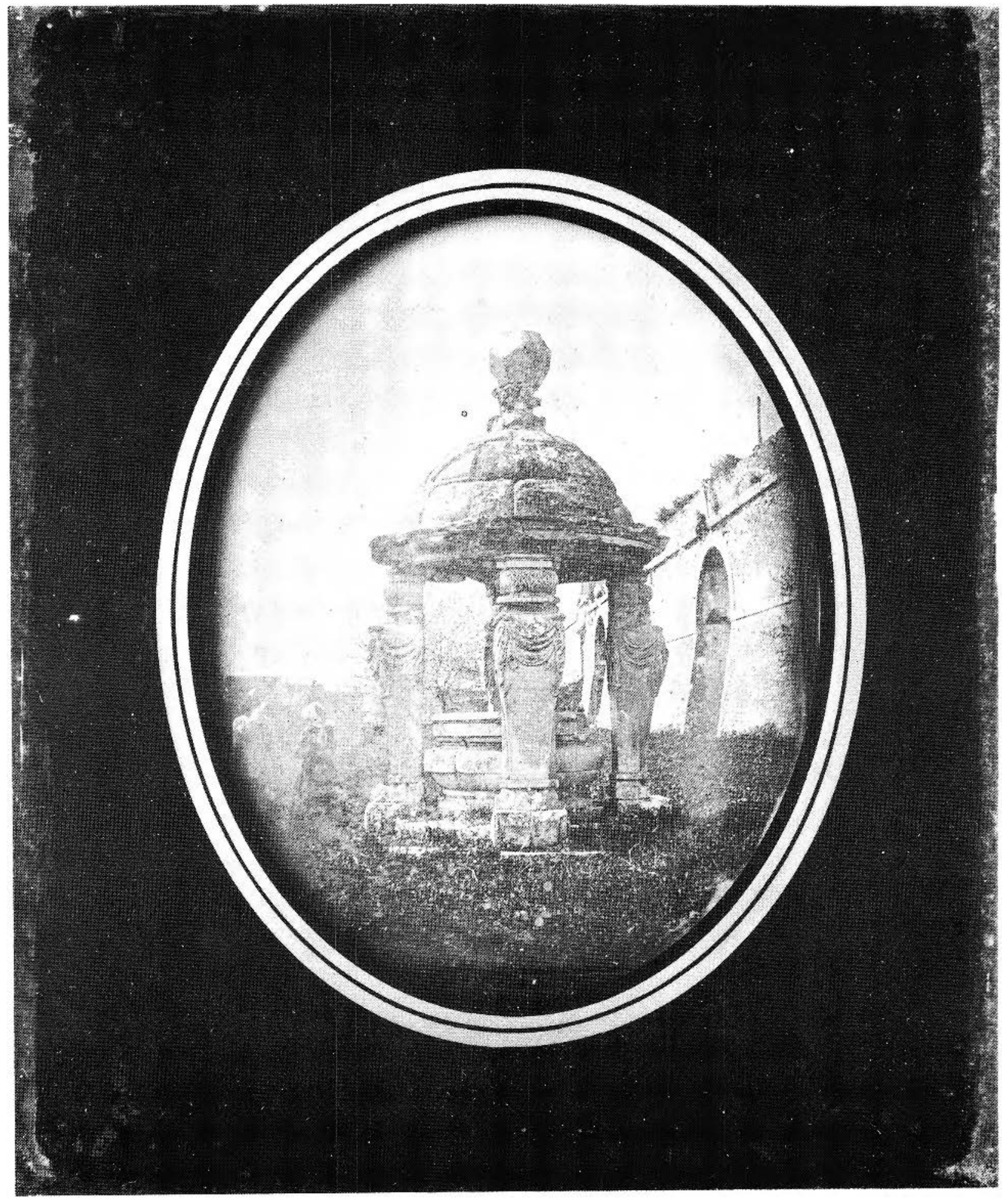

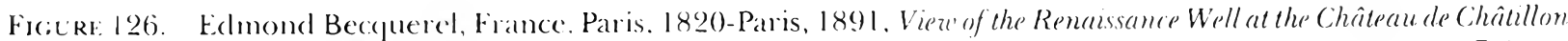
at Chatillon-sur-Loing, France, Jean (;oujon, sculptor-designer, daguerreotype, eanly $184(0)$. (9.5) $\times 7.5(\mathrm{~m}$. PHI987:0]53. Collection Centre Canadion d'Architecture/Canadian Centre for Architecture. Montréal. 


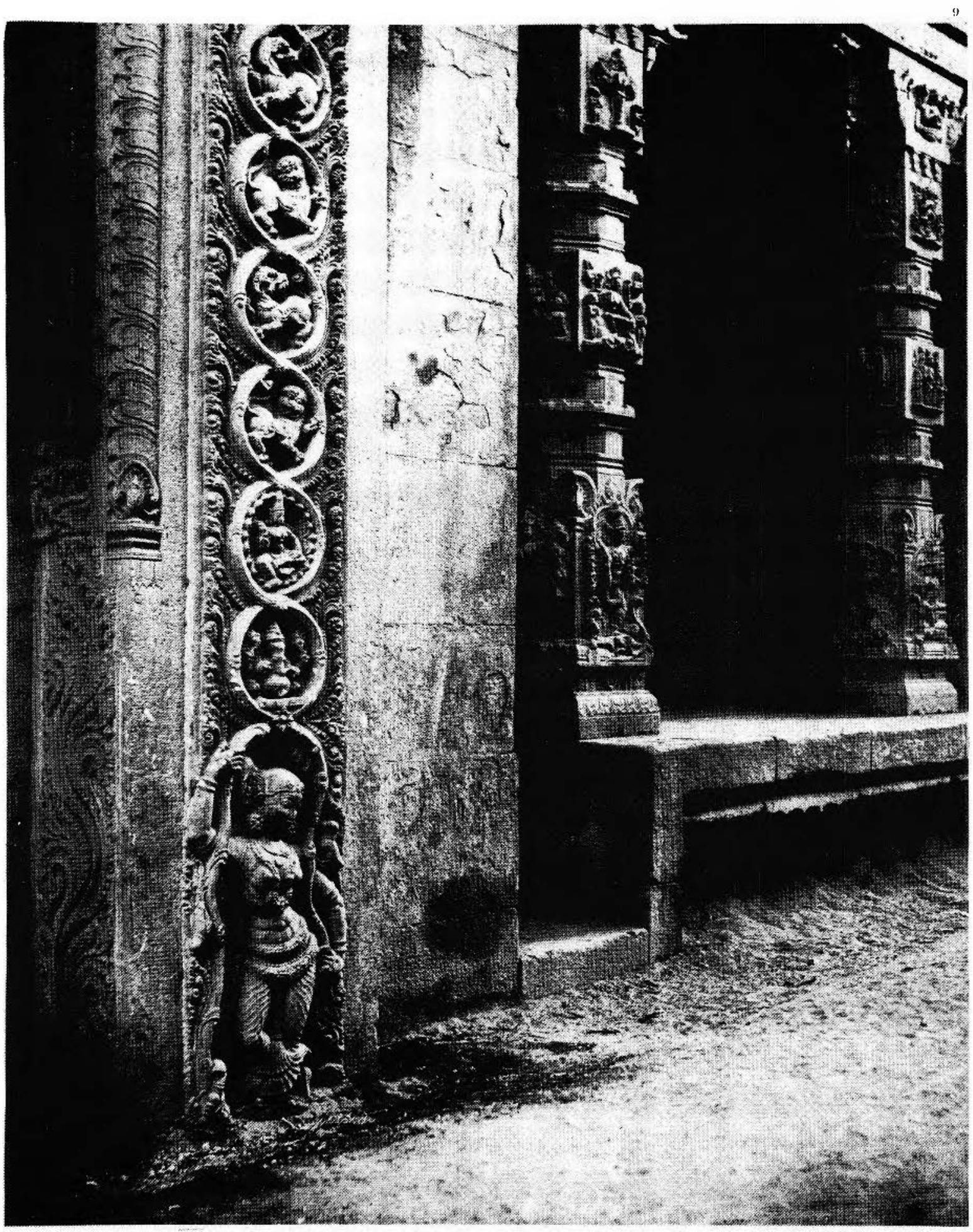

Figire 127. I.innacus Tripe, Great Britain, 1822-1902, active in Burma and India, 1854-70, Pillars in the Recessed Portico in the Raya (Bopuram with the Base of (One of the Four Sculptured Monoliths from a waxed-paper negative, 1858 , $35.5 \times 28.4 \mathrm{~cm}$, plate 9: "Bascment of a Monolith in the Raya Gopuram," from Pholographic Views in Madura. By Captain 1.. Tripe, Government Photographer. Part 1. With Descriptive Notes by M. Norman, Esq., M.C.S., 1858. PHTR1988:002:009, Collection Cientre Canadien d'Architecture/Canadian (icntre for Architecture, Montréal. 


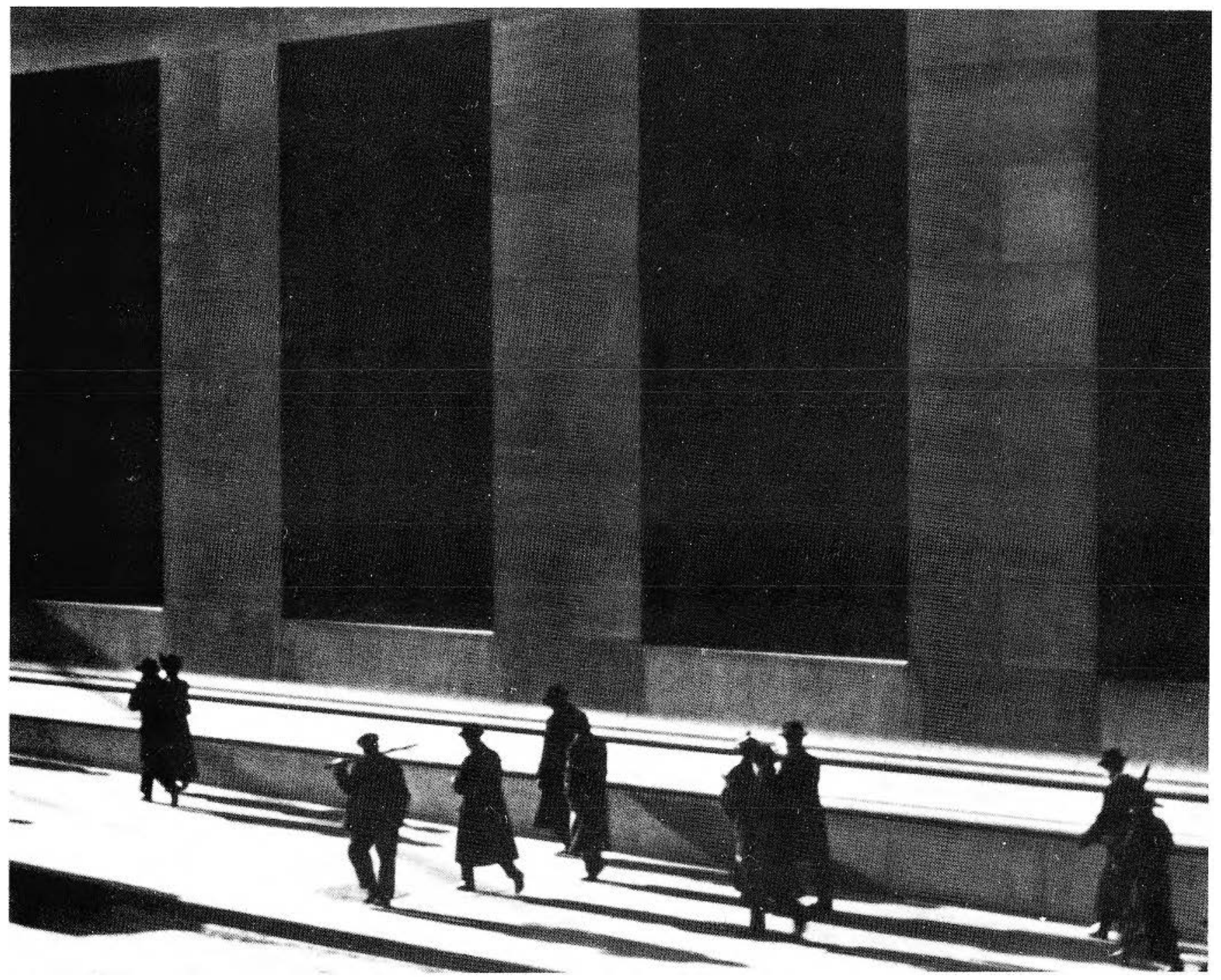

Figure 128. Paul Strand, United States, New York 1890)-Orgeral, France, 1976, Wall Strept, Neru York, 1915, Partial vieun of the exterior of the Morgan (suaranty Trust Company, Neil York (ity, Trowbridge and Livingstone, Architects, platinum print (mercury toned), 1915, building constructed 1913-14, 24.8 $32.3 \mathrm{~cm}$. PH1985:0224, (oollection Centre Canadien d'Architecturc/Canadian Centre for Architecture, Montrcal. Copyright (C) 1971 Aperture Foundation Inc.; Paul Strand Archive. 


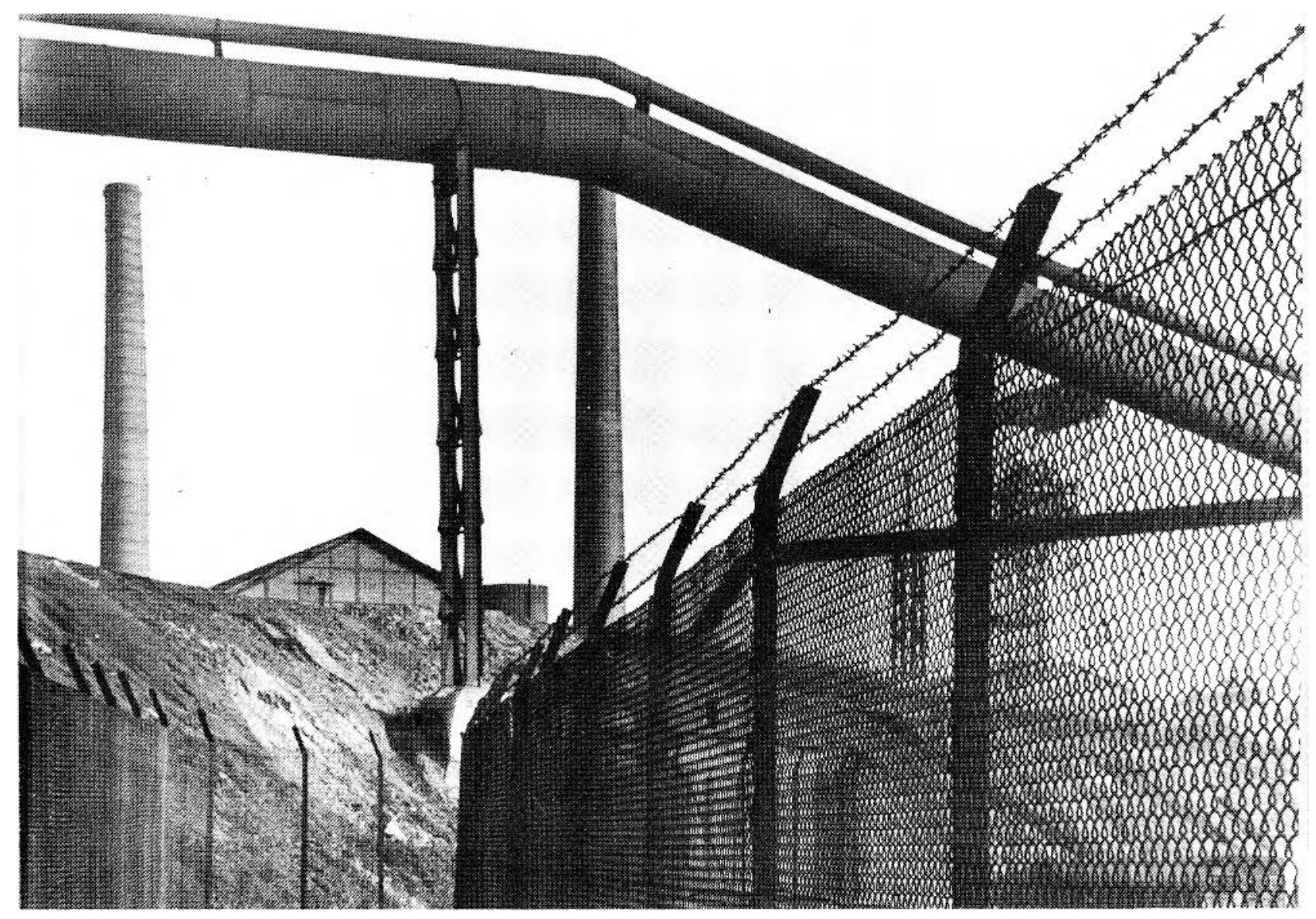

Figure 129. Albert Renger-Pat/sch, Germany, Würzburg 1897-Womcl 1966, Industrial L.andscape, Ruhr District, West Germany, gelatin silver print, 1929, 27.2 ×37.6 cm. PHI986:00)38, Collection (entre Canarlien d'Architecture Canadian Centre for Architecture, Montréal. Reproduction courtesy of Kicken-Pauseback, Cologne, Germany. 

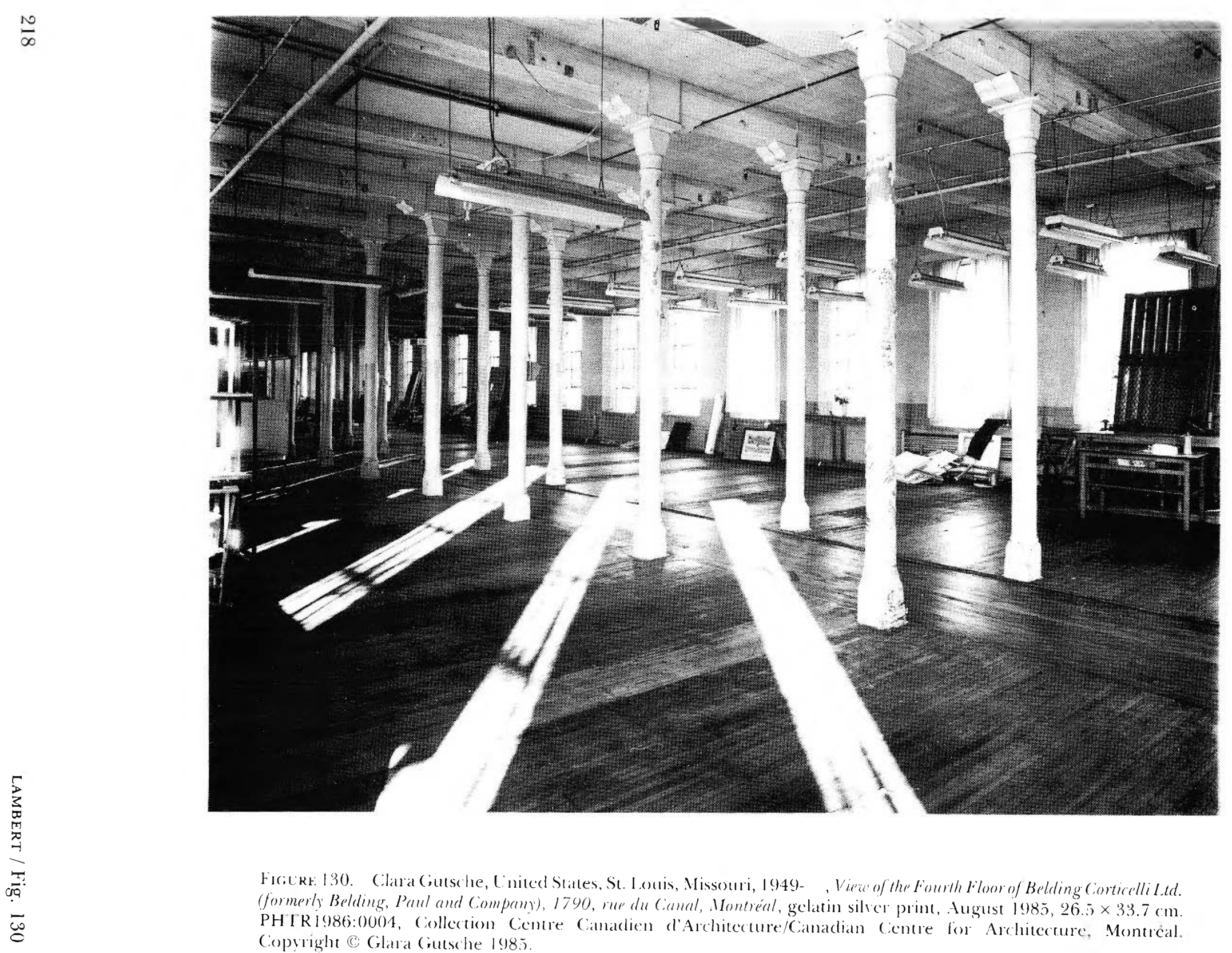

Ficitre 130. Clara Gutsche, Lnited States, St. I.ouis, Missouri, 1949- , View of the Fourth Filoor of Belding Corticelli L.td. (formerly Belding, Paul and Company), 1790, me du Cannal, Montréal, gelatin silver print, August 1985, 26.5 $\times 33.7 \mathrm{~cm}$ PHTR1986:0004, Collection Centre Canadien d'Architecture/Canadian Centre for Architecture, Montrá. Coprright $\mathbb{C}$ Glara Gutsche 198.5. 